\title{
Interaction between grasses and Epichloe endophytes and its significance to biotic and abiotic stress tolerance and the rhizo- sphere
}

\author{
Kendall Lee ${ }^{1}$, Ali Missaoui1 ${ }^{1,3}$, Kishan Mahmud ${ }^{2}$,Holly Presley ${ }^{1}$, and Marin Lonnee ${ }^{3}$
}

${ }^{1}$ University of Georgia, Institute of Plant Breeding, Genetics and Genomics

2 University of Georgia, Center for Applied Genetic Technologies

${ }^{3}$ University of Georgia, Department of Crop and Soil Science

*Correspondence: Ali Missaoui; cssamm@uga.edu Tel.: 706-542-8847

\begin{abstract}
Cool-season grasses are the most common forage types in livestock operations and amenities. Several of the cool-season grasses establish mutualistic associations with an endophytic fungus of the Epichloe genus. The grasses and endophytic fungi have evolved over a long period of time to form host-fungus specific relationships that confer protection for the grass against various stressors in exchange for housing and nutrients to the fungus. This review provides an overview of the mechanisms by which Epichloe endophytes and grasses interact, including molecular pathways for secondary metabolite production. It also outlines specific mechanisms by which the endophyte helps protect the plant from various abiotic and biotic stressors. Finally, the review provides information on how Epichloe infection of grass and stressors affect the rhizosphere environment of the plant.
\end{abstract}

Keywords: endophyte, epichloe, forage, mechanisms, stress

\section{Introduction}

Poaceae is a large taxonomic family of grasses. Most grasses used for forage originated from Europe, Africa, and western Asia, with over 600 species from this family being used worldwide for livestock forage [1]. Typically these grasses are cross-pollinated, polyploids with complicated genomes. In America, grasses occupy over 238 million ha of land used for forage production [2]. Forage grasses are essential to livestock operations and can be native or introduced, perennial or annual, and cool-season or warm-season depending on the region and farmer preference. Pasture-fed beef and dairy are gaining popularity in the United States and are already the primary mode of livestock production in places like New Zealand, South America, and Europe. The hardiness and endurance of the grass is relied on by livestock farmers. Persistence under grazing pressure, high nutritive value, drought resistance, insect resistance, high yield, are important criteria for the sustainability of forage production and climate resilience of these species. Temperate grasses, also known as cool-season, are the most important class of forages that sustain the supply of most of the world's beef and dairy products [3]. Several cool-season grasses are known to establish a fungal association with Epichloe species of fungi that confer abiotic and biotic stress tolerances to the grass. Biotic stressors refer to living elements and include weeds, insects, and diseases that affect plant health and compromise yield. Abiotic stressors refer to non-living elements that could harm the crop such as drought and flood. A major difference between forage grasses and other crops is that grazing livestock is the main biotic stressor. Withstanding grazing pressures is one of the most important stress tolerances forage grasses need to possess. Producers often choose not to spray chemical pesticides for insects in grazing situations due to the cost versus return of the treatment but spraying weeds is a more common [4]. Abiotic stress tolerance is necessary in forage grasses as a less rigorously managed crop. Most pastures are subjected to drought, flood, nutrient deficiency, high temperature, frost, etc... without much intervention from producers. This leads producers to search for forage grasses that are naturally tolerant to many of these stresses. In this review we will highlight how the 
Epichloe endophyte and host grass evolved together, the mechanisms by which the fungi provide stress tolerance and resistance to its host, and how this association may affect the plant's rhizosphere.

\section{Evolution of Epichloe mutualistic association with grasses}

Epichloe fungi often form symbiotic mutualistic relationships with cool-season grasses. Nearly $30 \%$ of coolseason grasses across the globe are known to form a relationship with epichloe species [5]. The fungus provides the plant with protection through secondary metabolite production and the plant provides nutrients and accommodation to the fungus. The common secondary metabolites, called alkaloids, produced by Epichloe species are lolines, indolediterpenes, peramines, and ergot alkaloids. These different alkaloids confer protection against a variety of abiotic and biotic stressors. Peramines and lolines are known for their insect deterrence and insecticidal properties, whereas ergot alkaloids and indole diterpenes have mammalian toxicities [6].

Epichloe fungi can have sexual and/or asexual transmission. While sexual Epichloe mutualism with grasses does occur, such as E. typhina with Dactylis glomerata (orchard grass), it is more common that asexual forms of the fungus inhabit perennial cool season species [7]. Some common asexual Epichloe relationships with cool-season grasses include E. coenophiala with Festuca arundinacea (tall fescue), E. festucae var. lolii with Lolium perenne (perennial ryegrass), and E. occultans with Lolium multiflorum (annual ryegrass).

Phylogenetic, genetic, and physiological evidence suggest that Epichloe endophytes and cool-season grass hosts co-adapted together over a long period of time [8,9]. Most of the mutualistic Epichloe species are asexually reproduced by vertical transmission. Evolutionary theory states that vertical transmission is an indicator of a strong mutualist as asexuality leads to very little response to selection due to decreased recombination and genetic diversity [8,10]. This contrasts with the host that reproduces sexually and therefore can quickly respond to selective pressures. This system of the host having increased gene flow compared to the symbiont is consistent with Law's Hypothesis which states that loss of sexual reproduction is often a precursor to mutualism as it reduces the chance of the symbiont becoming pathogenic again. Many asexual Epichloe species are interspecific hybrids that arose from sexual progenitors. The exact mechanism by which hybridization occurred is unclear but it likely arose from the fusion of hyphae and nuclei or abnormal segregation in mating between sympatric Epichloe species [11]. The change from sexual reproduction to asexuality eliminates a primary mechanism of pathogenicity [12]. The asexual interspecific hybrid species often show increased fitness compared to their sexual progenitors by alkaloid gene loci pyramiding [13], which likely led to now more than half of Epichloe species being hybrids [12]. Post-hybridization, co-adaptation of the fungus and grass occurs in a host-specific manner. These facts present a strong argument for a long evolutionary history of mutualism between Epichloe species and their grass hosts.

It is likely that asexual hybrid Epichloe symbionts co-diverged at the same time [8,9]. Previous research using these genes has found that many Epichloe species display co-phylogeny with their grass host [14]. Schardl et al. [9] found that early cladogenesis events corresponded between Pooidae (a subfamily of Poaceae) and Epichloe. They also found that within the tribe Poeae, a group that contained Lolium species showed mirrored topology to their Lolium-associated-clade endophytes. These results provide evidence for co-divergence between the species.

\section{Mechanisms of Interaction Between Grass and Endophyte}

Epichloe species are known for producing bioprotective compounds known as alkaloids [15]. The most commonly produced alkaloids are lolines, indole-diterpenes, ergot alkaloids, and peramines. Genes or gene clusters have been identified for these alkaloids. These gene clusters consist of 10 to 12 genes for EAS (ergot alkaloid), IDT (indole-diterpene) and LOL (loline) depending on the species [16]. A single gene, PER, was found to be responsible for peramine synthesis [17]. The pathways for each alkaloid are complex with many intermediate metabolites produced that affect alkaloid composition [18]. Endophyte infected ( $E+)$ grasses have been documented to gain protection from 
drought, insects, nematodes, cold, flooding, heavy metals, pathogens, and mammalian herbivory [19]. Loline and peramine alkaloids are known insect deterrents and insecticides [20] [21]. Ergot alkaloids and indole-diterpenes alkaloids have mammalian toxicity properties as well as some insect protection [22]. E+ plants can withstand drought and edaphic stress at a higher level than uninfected (E-) [21]. Research shows that endophytes can interact with the grass host to modify the physiology and biochemistry of the plant, such as rolling and shedding leaves under drought stress [23]. These types of modifications likely translate to other stressors as overall yield and persistence in a variety of environments are higher for E+ grasses than E- grasses [21,24,25]. The exact protections that the endophyte provides depend on alkaloid genes present as well as the genetic interplay between the endophyte and the host.

The exact mechanisms that lead to the successful mutualism between Epichloe species and cool-season grasses are not well defined. Most plants, when faced with a fungal invasion will activate defense responses such hypersensitive response triggered cell death. Epichloe species do elicit defense responses from non-host plants [26]. However, endophyte-infected host grasses do not produce these responses against the endophyte. The endophyte lives and grows in the intercellular space within the plant, in synchrony with the plant maturation [20]. The fact that the plant does not react to the endophyte as a pathogen, and that the endophyte only grows in pace with the grass suggests significant cross-talk between the two species. Research has shown that endophyte-infected grasses have higher levels of phenolic compounds and other antioxidants compared to endophyte-free grasses [27]. Other studies have postulated that the grass recognizes the endophyte through increased production of resveratrol and chitinase, as well as phenolics [28]. Reactive oxygen species (ROS) have been shown to regulate the fungal growth within perennial ryegrass. Tanaka et al. [28] identified a fungal mutant with an insertion in the NADPH oxidase gene noxA, which leads to dramatically increased fungal growth within the plant. NoxA is a hydrolase enzyme that regulates superoxide production. They detected ROS in the non-mutant mutualistic fungus but not in the nox A mutant leading them to conclude that ROS restricts fungal growth. Further ROS production is regulated by SakA (stress-activated mitogen-activated protein kinase A). It was found that when SakA is deleted, ROS production increases [26]. It is well known that grasses and endophytes can both change the metabolite pathways within themselves to produce different compounds [29], but research has shown that in some cases, the plant and endophyte can work together to produce a metabolite that could not be synthesized by either species alone [30]. There is also evidence that the cross-talk will vary between plant parts. Transcriptome analysis found that fungal gene expression differs between floral and vegetative parts of Epichloe infected grasses [31]. This finding provides further evidence for the complicated nature of this mutualism.

Other essential factors in the mechanisms of mutualism have been found. Two Rho GTPases, Cdc42 and Rac4 have been implicated in intercalary growth regulation and hyphal network formation [32]. ProA, a transcriptional regulator, appears to work in tandem with symB/symC, membrane-associated proteins, to act on NOX to regulate fungi growth [33]. Additionally, Green et al. [33] found a component of STRIPAK (striatin-interacting phosphatase and kinase) called MobC to be important for mutualism and hyphal cell to cell fusion. 

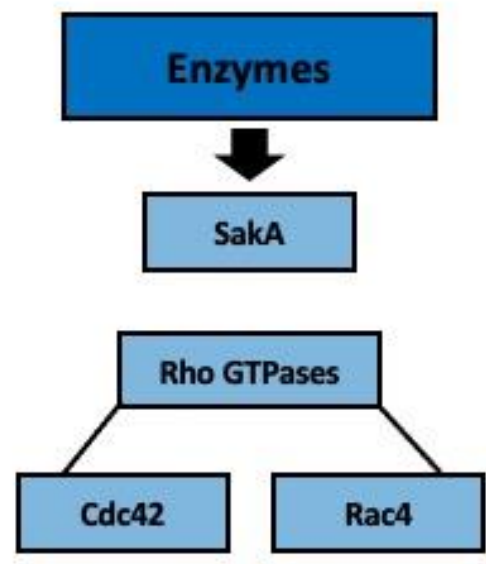

$\longrightarrow=$ types of GTPases

$---=$ connection between compounds

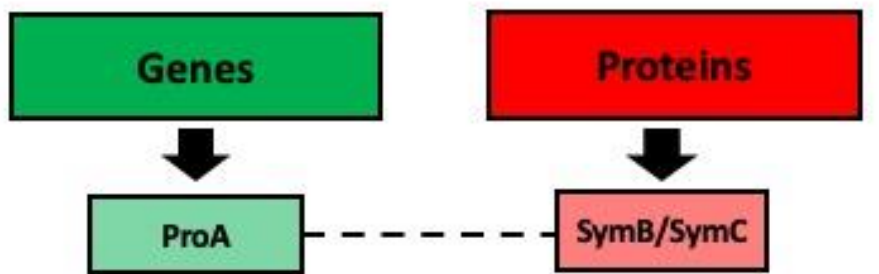

NoxA

MobC

Fig. 1. A visual representation of putative enzymes, genes and proteins necessary for Epichloe endophyte and grass mutualism. SakA and NoxA regulate ROS production. Cdc42 and Rac4 regulate intercalary and hyphal network growth. ProA works with SymB/SymC to regulate the endophyte growth. MobC is necessary for symbiosis of the endophyte and grass.

Specific genes have been found to be essential in the change from pathogenic infection to a mutualistic relationship in the endophyte and the host grasses. Eaton et al. [26] disrupted components of the Nox complex and SakA, previously revealed as necessary for mutualism, in perennial ryegrass infected with E. festucae and determined the transcriptomic changes that occurred. They found that certain classes of genes were up or down-regulated in the grass, most notably genes involved in pathogen defense, transposon activation, hormone biosynthesis and response [26]. Further work carried out by Eaton et al. [34], identified 182 specific fungal genes associated with mutualism in the perennial ryegrass and E. festucae system. They identified the upregulation of genes that encode degradative enzymes, transporters, and primary metabolism and the downregulation of genes that encode for secondary metabolism and production of small-secreted proteins. These are genes involved with nutrient-starvation response and indicate that disruption of the mutualism results in the endophyte taking in more nutrients from the host including cell wall components, consistent with pathogen feeding patterns. Further evidence of transcriptome changes that aid in mutualism has been found. Schmid et al. [35] discovered gene expression changes in fungi in growing grass compared to those in mature grasses with genes shifting from hyphal growth to alkaloid production [35].

\section{Environmental effect on endophyte/grass associations}

The environment can play a substantial role in Epichloe endophyte infection and production within the grass hosts. Temperature, season, humidity, climate, soil nutrients, etc... have been shown to have an effect on endophytes. Alkaloid concentrations can be different in the same grass/endophyte combination in different geographical locations [36]. It is known that endophytes tend to be more prevalent in the plant in summer than in winter. Seeds exposed to hot, humid weather for an extended period can lose their endophyte. Very cold weather may affect fungal transmission to the grass progeny [20]. Temperature can also influence individual alkaloid production [37] and soil nutrients can influence endophyte infection. Rasmussen et al. [38] found that perennial ryegrass had lower levels of endophyte concentration 
and alkaloid production in soils that were provided with high levels of nitrogen and carbohydrates. One may think that increased nutrients to the grass would only increase the fungal mutualist. However, research investigating the environmental effects on the Epichloe-grass relationship in natural and agronomic systems has mixed results. Every host of a mutualistic relationship is performing a cost benefit analysis to ensure that the cost of the endophyte does not exceed the gain the host obtains [39]. In stressful environmental conditions, the E+ plants persist better than E- plants. This is the basis of the agronomic use of these grass-endophyte associations. However, reports of the endophyte overtaxing the host in low-input situations have been reported in some grasses leading to decreased yield [40,41]. It appears that in some situations, the endophyte does tax the plant more heavily, but the benefits of the fungus still outweigh the costs. Bacon [42] found that while E+ seeds needed more water to germinate and E+ seedlings required more nutrients, the overall E+ grasses were more tolerant in conditions of abiotic stress. These findings highlight the importance of the specific endophyte-host relationship. Also, it is possible that different environments can change the effect of the same host-symbiont relationship due to phenotypic plasticity and potential epigenetic changes [40]. How the environment changes mechanisms by which endophytes and grasses interact is not well understood.

\section{Stress Tolerance Mechanisms}

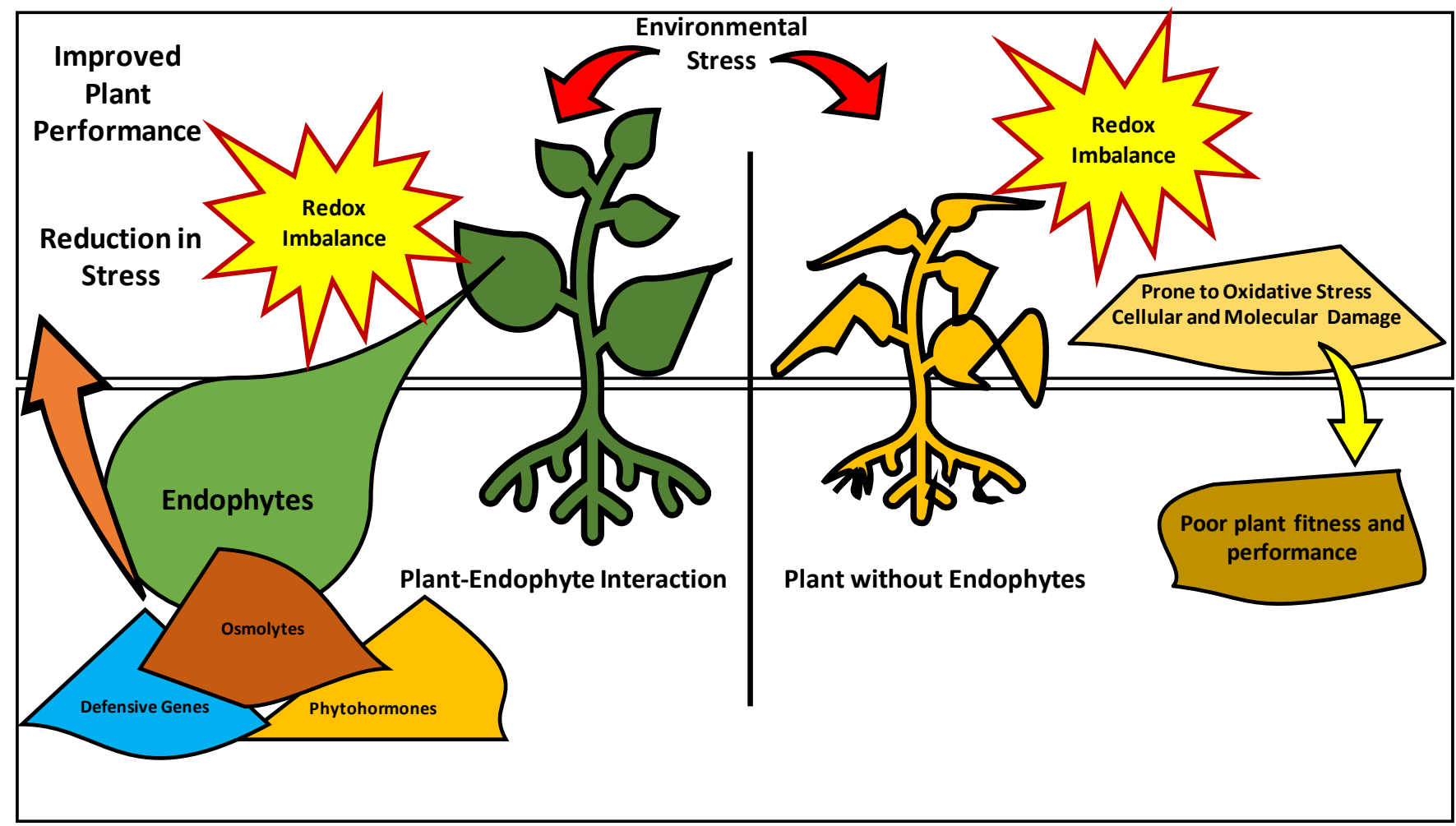

Fig. 2. Environmental stressors impact on endophyte infected and non-infected plants. Stress causes redox imbalances that lead to oxidative damage. In endophyte free plants, there is little to mitigate this damage. Endophytes upregulate defensive genes and produce osmolytes and phytohormones that are protective against many stressors and reduce damage done by redox imbalances. This improves the overall plant performance.

\section{Drought}

Several studies cite the connection between Epichloe infected grass and drought tolerance. Three main mechanisms are thought to be the reason for this: increased root biomass [43-45], better regulation of stomatal closure, and higher accumulation of solutes for osmotic regulation [46]. Not only were higher levels of sugars, proline, and glutamic acid found in drought-stressed E+ tall fescue found, but higher levels of mannitol and loline alkaloids were also discovered 
[47]. These are fungal-derived metabolites that could act as osmotic regulators. Gene expression relating to drought tolerance was found to be altered in perennial ryegrass infected with Epichloe festucae. Dupont et al. [48] showed that drought-related genes were downregulated in E+ perennial ryegrass, decreasing the grass's drought sensitivity. The endophyte likely makes up for this reduced sensitivity by producing the osmotic protective solutes. Endophyte infection also increases gene expression of galactinol synthases in the grass, which produces osmo-protective oligosaccharides [48]. The endophyte promotes the production of antioxidant enzymes such as superoxide dismutase, ascorbate peroxidase, catalase, and guaiacol peroxidase under heat and drought stress which mitigate damage done by the accumulation of ROS [49].

\section{Salinity}

Studies have shown that grasses infected with an Epichloe endophyte outperform uninfected plants in situations of salt stress [50-52]. $\mathrm{Na}+$ is an important regulatory element for ion content in cells but can become toxic at high levels. The endophyte appears to regulate ion concentration and help with nutrient absorption as ways to counteract $\mathrm{Na}+$ stress [52]. Reza Sabzalian et al. [50] found that when presented with salt stress, there was less $\mathrm{Cl}$ - and $\mathrm{Na}+$ in $\mathrm{E}+$ fescue roots and an increase in $\mathrm{K}+$ in the shoots, compared to the uninfected fescues. Creating a higher ratio of $\mathrm{K}+$ to $\mathrm{Na}+$ could help balance ion content. Other studies show increases in $\mathrm{P}$ and $\mathrm{N}$, in addition to $\mathrm{K}+$ as ionic adjustment ameliorations [52]. In addition to regulating ionic elements, the endophyte may also increase net photosynthesis, which is often lowered under abiotic stress [53]. Much like with drought stress, the osmo-protective solutes that endophytes produce also play a function in salt stress. Notably, glycine betaine has been found to be higher in Epichloe infected sorghum and is good at mitigating oxidative stress [54]. Increases in other enzymatic and non-enzymatic antioxidants have been found that help keep ROS from accumulating under salt stress [54].

\section{Heavy Metals}

Heavy metals in the soils can become toxic to plants and interfere with biological processes. There is evidence that endophyte infection can alleviate symptoms of heavy metal stress. Campbell et al. [55] found that drunken horse grass infected with E. gansuensis had more biomass, tillers and was taller in height than uninfected grass under cadmium stress. Similarly, a study found E+ perennial ryegrass shoot biomass was better in E+ under cadmium stress and had increased amounts of $\mathrm{H}_{2} \mathrm{O}$ and chlorophylls a and $\mathrm{b}$ [56]. When presented with $\mathrm{Zn}$ stress, $\mathrm{E}+$ perennial ryegrass showed less $\mathrm{Zn}$ accumulation in the leaves and had a higher tiller number and overall biomass. The overall better performance is likely due to the lack of $\mathrm{Zn}$ in the leaves, where it could interfere with photosynthetic processes [57]. Antioxidants are important to increase osmotic regulation and photosynthesis, and to counteract the ROS accumulation associated with heavy metals [58]. In general, Epichloe endophytes likely ameliorate the effects of heavy metals by increasing antioxidant enzyme activity as well as maintaining plant growth.

\section{Low Nutrients}

A variety of studies have shown Epichloe infected grasses could be more tolerant to low nutrient inputs [59-62]. Wang et al. [59] studied the mechanisms by which E+ drunken horse grass was more tolerant to low $\mathrm{N}$ environments. They found that the endophyte regulates G6DPH, a pentose phosphate pathway enzyme associated with abiotic stress tolerance, as well as glutathione activity, NADPH ratio and photosynthesis. The same group also studied $\mathrm{N}$ use efficiency in the same grass/endophyte association. They found an increase in N-related enzyme activity, including an increase in nitrate reductase leading to increased NO3- and an increase in nitrite reductase leading to increased $\mathrm{NH}^{+}$. The creation of these substrates is vital for $\mathrm{N}$ use in plants. Glutamine synthesis was also increased in $\mathrm{E}+$ plants which is essential in converting inorganic $\mathrm{N}$ to amino acids [59]. Phosphorus is another nutrient essential for plant growth and a deficiency in P can lower the bioavailability of other nutrients. A study conducted on drunken horse grass and $E$. 
gansuensis found that the E+ grass was more tolerant to low P than the E- grass. This is likely due to the endophyte regulation of certain amino acids, amino acid metabolism and organic acids were found in E+ plants, which helps with nutrient metabolism and photosynthesis [62]. Additionally, an increase in vanillin, a ROS scavenging compound, which helps decrease oxidative damage was found in E+ grass [62]. Nutrient cycling in endophyte-infected plants is commonly tied to changes to the surrounding microbiome. The effects of the endophyte on vital microorganisms will be explored in a later section.

\section{Cold}

The effect of endophyte infection in grasses for cold tolerance is mixed. Heineck et al. [63] found no differences in freezing tolerance in E+ and E- perennial ryegrass. However, Chen et al. [64] found that E+ drunken horse grass had higher seed germination rates compared to E- grass in cold conditions. This group analyzed gene expression changes in the E+ grass and found 152 differentially regulated genes, including genes involved in fatty acid biosynthesis, stress response, and protein turnover. Upregulation of unsaturated fatty acids was found which is consistent with cold tolerance [65]. It is interesting to note that ergot alkaloid compounds were accumulated at higher levels in cold stressed Epichloe infected Festuca sinensis, indicating that cold has some effect on the fungi alkaloid content [66].

\section{Flood}

Much like with cold stress, the effects of the Epichloe endophyte on waterlogging stress are mixed. Arachevaleta et al. [67], initially found that there was no difference in E+ and E- tall fescue under water stress. Similarly, Adams et al. [68] investigated two types of bluegrasses, one that lives in water logged areas and one that lives in drier environments. They found that E+ infection did not change performance in flood conditions. However, Song et al. [52] found that the endophyte-infected wild barley had increased tolerance to flooding. They found that the endophyte increased production of proline (an osmotic regulator), had decreased electrolyte leakage and decreased malondialdehyde content, lipid peroxidase damage indicator. These results suggest the endophyte aids in osmoregulatory processes and protection from oxidative damage [69]. Wang et al. [70], conducted a waterlogging study on F. sinensis and found that while all plants suffered under flood conditions, the E+ plants had higher root to shoot ratios. This could be a result of increased photosynthesis even under stress.

\section{Pathogens}

Disease resistance is key in any crop production. Diseases can arise from bacteria, fungi, viruses, parasites, or other microorganisms. The ability of Epichloe fungi to protect the host species from a variety of fungal pathogens is well documented [71]. The mechanisms by which fungal endophytes can protect the host plant against disease are numerous. For fungal pathogens, one of the most apparent mechanisms is that the endophyte occupies the ecological niche that the pathogen would inside the plant [72]. Some Epichloe endophytes such as E. festucae and E. inebrians produce a secreted antifungal protein, Efe-AfpA, that directly impedes fungal pathogens [73]. More generally, endophytes can ease disease damage by increased production and activity of antioxidants. ROS can accumulate under pathogen stress and cause damage. Endophytes may produce compounds like superoxide dismutase and peroxidases that scavenge for ROS. Studies have also found an increase in proline, another ROS scavenger, and a decrease in malondialdehyde in E+ perennial ryegrass under pathogen stress compared to E- perennial ryegrass [74-79]. Salicylic acid (SA) is essential in plant pathogen defense. Once triggered, SA will lead to the activation of resistance genes which will then make pathogenesis related proteins. Epichloe endophytes are likely pathogens turned mutualists and therefore their presence could make the plant host more primed for pathogen response. In fact, Wang et al. [80] found that Chinese wild rye that was $\mathrm{E}+$ produced more SA when presented with two different pathogens as compared to the E- grass. They also found increased lignin content, which has been shown to be protective to pathogens [81]. However, some research has found 
downregulation of SA-related genes [48]. Suppression of SA pathways usually enhances jasmonic acid (JA) pathways. Further evidence for enhanced JA pathways is the upregulation of gene TF441, which may produce precursors to JA, but the effects of this are unverified [82,83]. The quinate and shikimate pathways are important in pathogen defense. Rasmussen et al. [84] found increased amounts of both compounds, as well as phenols, in E+ perennial ryegrass. Phenolic compounds are known to be important in plant defense and are part of the bioprotective phenylpropanoid pathway [85]. Dupont et al. [48] 2015 found upregulation in genes encoding for enzymes involved in phenylpropanoid production. Other studies have shown that endophyte infection not only increases in phenolic compounds but also volatile organic compounds (VOCs). VOCs have been shown to inhibit fungal growth [86]. Zhang et al. [87] found that volatile oils extracted from E+ drunken horse grass significantly reduced fungal growth compared to E- grass. VOCs can also function in plant stress response communication [88]. It is well described that certain Epichloe produced alkaloids peramine and loline have anti-insect properties that could deter infection. Endophytes reduce viral infection in host plants namely by reducing insect vectors such as aphids. The insect deterrence mechanisms will be explored in another section [89].

\section{Nematodes}

It is well known that wild-type endophyte-infected grasses have a negative effect on a variety of nematodes [9092]. Various studies showed the ability of Epichloe infected perennial ryegrass and tall fescue to be resistant to endoparasitic nematodes such as root-knot nematodes and Pratylenchus scribneri [93]. However, ectoparasitic nematodes do not appear to be affected. Kimmons et al. [90] found that endophyte-infected tall fescue was successful in controlling P. scribneri and Meloidogyne naasi but had very little effect on the ectoparasitic Helicotylenchus pseudorobustus. A more robust study from Guo et al. [94] tested the effects of E+ plant-soil on 11889 soil nematodes from 37 different genera. They found significant differences between plant-soil types with the plant-parasitic index lower in E+ plant-soil than E- plant soil. This is interesting because endophytes do not infect the below-ground tissue of the grass.

Nematode control may be linked to one or more of the main alkaloids produced by the endophyte. It is thought that the ergot alkaloid is the compound toxic to nematodes. This is the same alkaloid that is toxic to mammals. It is interesting to note that peramine is the alkaloid that confers resistance to insects, but strains of endophyte that contained peramines but no ergot alkaloids did not confer high levels of resistance to Pratylenchus spp [95]. In fact, these strains had no better effect on controlling nematodes than endophyte-free strains of tall fescue. A later study found that the ergot alkaloid compound ergotamine was found to control P. scribneri in vitro [96]. However, a study carried out with perennial ryegrass found that the grass lacking ergot alkaloids but containing other alkaloids was still able to control $P$. scribneri just as well as the grass that did have the ergot alkaloids [97]. There is no published concrete evidence for the mechanisms of nematode control but there are few theories. One could be that the endophyte changes root exudates in some way that is detrimental to nematodes. It is also possible that morphological changes in the plant, like epidermal thickening, could lead to decreases in nematodes. As far as nematode tolerance in E+ grasses, this could also be due to the other benefits that the endophyte confers that overall makes the grass healthier.

\section{Insects}

Insect tolerance and avoidance is an area that has been heavily studied in Epichloe infected grass species. There are at least 45 different insect species that have been found to be negatively affected by Epichloe alkaloids [98]. Insect resistance is mainly linked to peramine and loline alkaloids, but indole-diterpene alkaloids have also shown insecticidal properties [27,99]. $\mathrm{N}$-acetylnorloline and $\mathrm{N}$-formyloline are loline alkaloids that have been shown to be toxic to different insects [100]. Bastias et al. [83] found that lolines likely have a profound effect on aphid metabolism. The energetic cost of detoxification leads to decreases in development and reproduction [101]. Expoxy-janthrims are the main indole- 
diterpene alkaloid that confers insect toxicity, however, nodulisporic acids are also indole-diterpene metabolites that were shown to be toxic to certain insects by binding to arthropod specific glutamate-gated chloride channels [37,102]. Insect resistance can be further heightened by the grass-fungus interaction. Studies have shown that clipping leaf tissue can lead to increased production of lolines [103]. Much like in pathogen defense, plants utilize SA and JA systems for insect defense. JA pathways may be especially heightened in chewing and biting insects. The same mechanisms of endophyte infection that enhance these pathways in pathogens apply to insects. Incredibly, there is some research indicating that Epichloe endophytes can lead to multi-trophic interactions that benefit the plant. Fuchs et al. [104] found that $\mathrm{E}+$ plants attracted more hoverfly pupae and larvae. Hoverfly is a predator of aphids, therefore decreasing aphid infestation. They propose that volatile compounds may change phytohormones produced that have to do with olfactory attraction.

\section{Weed competition}

Epichloe infected grasses tend to do well amongst weed competition. This may be the indirect effect of the plant being overall healthier due to the endophyte. Some endophyte-infected grasses may take weed resistance further with allelopathy. Allelopathy is the ability of one plant to suppress another plant via chemical exudation. Some plants can release chemicals that prevent seed germination in other plant species or modify the microbiome to negatively affect other plant species. There is evidence that $\mathrm{E}+$ perennial ryegrass can suppress white clover with allelopathy playing a role $[105,106]$. Tall fescue has been reported to cause an allelopathic effect on various species including birds foot trefoil, red clover, and white clover [107]. More recently, Vázquez-de-Aldana et al. [108] found that red fescue infected with E. festucae increased the allelopathic potential of the red fescue on red and white clover. The endophyte may not be directly responsible for these allelopathic interactions as grasses can produce allelopathic chemicals, such as m-tyrosine, on their own [108]. However, it is known that endophytes that live in the above-ground parts of the plant can cause increased exudation of phenolic compounds and other metabolites from the roots, including syringic acid and myristic acid $[109,110]$. These acids have been shown to suppress certain weeds [111,112]. Phenolic compounds, like syringic acid, can interfere with enzymes that are important for the physiological processes of the plant, such as mineral uptake and photosynthesis. Myristic acid is a lipid that also has a negative effect on plant protective enzymes [113]. The prevention of activation of these important enzymes could inhibit or block plant growth.

Table 1. List of biotic and abiotic stressors, the potential tolerance/resistance that Epichloe infection could provide, the mediating biomolecules involved in resistance/tolerance and the mechanisms in which Epichloe infection works to combat the stressor

\begin{tabular}{|l|l|l|l|l|}
\hline Stressor & $\begin{array}{c}\text { Tolerance/ } \\
\text { Resistance } \\
\text { Potential }\end{array}$ & Mediating Biomolecules & \multicolumn{1}{|c|}{ Mechanisms } & References \\
\hline Drought & High & $\begin{array}{l}\text { proline, glutamic acid, } \\
\text { mannitol, loline alkaloids, } \\
\text { oligosacharides, } \\
\text { antioxidant enzymes }\end{array}$ & $\begin{array}{l}\text {-osmotic regulation via solutes and metabolites } \\
\text {-increased root biomass } \\
\text {-stomatal closure } \\
\text {-decrease in sensitivity to drought through } \\
\text { downregulation of drought genes } \\
\text { - mitigation of oxidative damage }\end{array}$ & {$[43-49]$} \\
\hline
\end{tabular}




\begin{tabular}{|c|c|c|c|c|}
\hline Salinity & High & $\begin{array}{l}\mathrm{K}+, \mathrm{P}, \mathrm{N} \text {, glycine betaine, } \\
\text { enzymatic and non- } \\
\text { enzymatic antioxidants }\end{array}$ & $\begin{array}{l}\text {-Ion concentration regulation } \\
\text {-Increase in net photosynthesis } \\
\text {-osmotic regulation via amino acids and betaine }\end{array}$ & [50-54] \\
\hline $\begin{array}{l}\text { Heavy } \\
\text { Metals }\end{array}$ & Medium & $\begin{array}{l}\text { Enzymatic antioxidants, } \\
\mathrm{H}_{2} \mathrm{O} \text {, chlorophyll }\end{array}$ & $\begin{array}{l}\text { - mitigation of oxidative damage } \\
\text {-increased growth rate }\end{array}$ & [55-58] \\
\hline $\begin{array}{l}\text { Low } \\
\text { Nutrients }\end{array}$ & High & $\begin{array}{l}\text { G6DPH, NADPH, N-related } \\
\text { enzymes, glutamine, amino } \\
\text { acids, antioxidants, organic } \\
\text { acids }\end{array}$ & $\begin{array}{l}\text {-enzymatic regulation } \\
\text {-amino acid metabolism regulation } \\
\text {-organic acid metabolism regulation } \\
\text {-mitigation of oxidative damage }\end{array}$ & [59-62] \\
\hline Cold & Low & Fatty acids, proteins & $\begin{array}{l}\text {-upregulation of fatty acid synthesis } \\
\text {-protein turnover changes }\end{array}$ & {$[63-66]$} \\
\hline Flood & Low & Proline, malondialdehyde & $\begin{array}{l}\text {-osmotic regulation } \\
\text {-increased photosynthesis } \\
\text {-mitigation of oxidative damage }\end{array}$ & {$[52][67-70]$} \\
\hline Pathogens & High & $\begin{array}{l}\text { alkaloids, antioxidants, } \\
\text { proteins, salicylic acid, } \\
\text { jasmonic acid, phenolic } \\
\text { compounds, volatile organic } \\
\text { compounds }\end{array}$ & $\begin{array}{l}\text {-occupation of the ecological niche } \\
\text {-antifungal protein production } \\
\text {-mitigation of oxidative damage } \\
\text {-increase salicylic acid production } \\
\text {-increase jasmonic acid precursors } \\
\text {-increase in precursors for shikimate and quinate } \\
\text { pathways } \\
\text {-phenolic compound and volatile organic } \\
\text { compounds } \\
\text {-deterrence of vectors }\end{array}$ & {$[48,71-89]$} \\
\hline Nematodes & Medium & alkaloids & $\begin{array}{l}\text {-potential change of root exudation } \\
\text {-potential cell wall thickening }\end{array}$ & [90-97] \\
\hline Insects & High & $\begin{array}{l}\text { Peramine and loline } \\
\text { alkaloids, jasmonic acid }\end{array}$ & $\begin{array}{l}\text {-alkaloid toxicity } \\
\text {-increase in jasmonic acid precursors } \\
\text {-potential multi-trophic interactions through } \\
\text { volatile compounds }\end{array}$ & $\begin{array}{l}{[27,37,83,98-} \\
104]\end{array}$ \\
\hline Weeds & Medium & $\begin{array}{l}\text { Phenolic compounds, } \\
\text { syringic acid, myristic acid }\end{array}$ & $\begin{array}{l}\text {-allelopathy via disruption of enzymes important } \\
\text { for plant physiological processes }\end{array}$ & {$[105-113]$} \\
\hline $\begin{array}{l}\text { Animal } \\
\text { Herbivory }\end{array}$ & High & $\begin{array}{l}\text { Ergot alkaloids, indole- } \\
\text { diterpene alkaloids }\end{array}$ & $\begin{array}{l}\text {-neurotoxicity } \\
\text {-metabolomic disruptions } \\
\text {-gut microbiome disruptions }\end{array}$ & {$[114-124]$} \\
\hline
\end{tabular}

\section{Animal Herbivory}

There is quite a bit of literature on the physiological effects that the endophyte-produced alkaloids can have on livestock [114-117]. Ergot alkaloids are the primary class of alkaloids that cause problems within United States cattle industry. Indole-diterpenes can cause negative effects in livestock like sheep and affect countries like New Zealand where sheep make up a large sector of their agricultural economy. 
Ergot alkaloids and indole-diterpenes create a neurological effect on mammals. Ergot alkaloids consist of clavines, lysergic acid and its derivatives, and ergopeptines with lysergic acid and ergopeptines sharing the same pharmacophore. This pharmacophore (D-lysergic acid) is structurally shaped very similarly to neurotransmitters like serotonin. Different alkaloid metabolites are thought to affect different physiological processes within certain mammals. For example, Trotta et al. [118] found that ergopeptine can influence vasoconstriction by binding to serotonin receptors found in the mesenteric blood vessels. Similarly, Zhang et al. [119] discovered that ergonovine has a cytotoxic effect on the smooth muscle cells of animals. Some more recent studies by Mote et al. [121],Mote et al. [122],Mote et al. [125] provide evidence that ergot alkaloid metabolites greatly affect the metabolome and gut microbiome of cattle and leads to toxicosis.

Non-livestock animal herbivores are also negatively affected by endophytes. A study carried out by Rudgers et al. [123] found that voles would avoid E+ tall fescue in favor of other surrounding vegetation. This was not the case in E- tall fescue plots. Conover et al. [124] found that Canadian geese lost body mass when feeding on E+ tall fescue compared to those feeding on E- tall fescue. Likely the same mechanisms by which alkaloids impact livestock also impact non-livestock animals.

\section{Epichloe infected Grass interaction with Rhizosphere Microbiome}

The rhizosphere is a small yet dynamic zone of biological activities and interactions between plant roots and soil microbiome [126]. A robust and diverse rhizosphere is a strong indicator of soil and plant health [127]. In terrestrial ecosystems, nutrient cycling and transfer of energy fluxes are closely tied with organic matter composition; a mixture of root hairs and exudates, active and decayed root cells, volatile organics and proteins. These energy substrates are collectively called rhizodeposits [128]. While these rhizodeposits have plant origin, soil microbes often contribute to the breakdown of nutrients that help allow for plant uptake and can influence plant growth and physiology [129]. Therefore, plants form a plant-microbe feedback loop with their rhizobiome which, in turn, affects soil and microbiome composition. Thus a comprehensive understanding of belowground root functionality and soil composition is required to explore the prospects of microbial symbiosis and its role on soil and grass species health [130-132]. The mechanisms of species coexistence are important in understanding and predicting species diversity aboveground and belowground [133]. Species coexist mainly by niche partitioning [134] (diversity in habitat, nutrient use, and survival strategy), especially in microbial communities, where they self-limit themselves as their useful resources decline. However, for sedentary species such as plants, the greatest challenge in realizing their coexistence mechanism is their high resource overlap with each other $[133,135,136]$. Recent, studies have indicated that plant-associated microbes could initiate and establish "self-limitation" for plants [133]. This 'extended plant phenotype' that includes plant-associated microbiota is critically important for plant productivity and survival where resources are transferred and allocated according to resource requirement $[137,138]$. The rhizobiome composition, diversity and functionality as well as the composition of rhizodeposits may experience changes depending on region, climatic variation, soil type, plant diversity and the presence of biotic and abiotic stressors [139-141]. Two main soil microorganisms need to be considered when analyzing the plant-microbiome relationship: i) bacteria; often considered the most important soil microbe. They are essential for decomposing residues and nutrient cycling. They especially help increase $\mathrm{N}$ and $\mathrm{P}$ availability to the plant [142]. Actinomycetes, a lignin-degrading gram-positive mycelial bacterium is worth mentioning in this case because often they are classified on their own; ii) fungi; mycorrhizal fungi establish symbiotic relationships with plants and help increase water and nutrient uptake and can help stabilize soil aggregates [143]. In legumes, mycorrhizal fungi also help improve $\mathrm{N}$ fixation. Studying and manipulating the rhizobiome of plants is becoming increasingly popular for productivity, especially under abiotic and biotic stress [144,145]. 


\section{Epichloe Effect on the Rhizosphere}

Endophyte infection has an effect on the grass rhizodeposition and therefore an impact on the microbiome. Rhizodeposition can change for several reasons but one aspect that may influence infected the grass's rhizodeposits is photosynthetic rate. Grasses infected with endophytes generally have higher photosynthetic rates which help increase yield [146]. Another way that infected tall fescue's rhizodeposition may be altered is by the secretion of alkaloids. Given that the alkaloids of the endophyte live inside the plant, it is not likely that they leach out into the soil via root exudates. However, one study did find a significant amount of alkaloids in the surface soils of an endophyte-infected tall fescue pasture [147]. These alkaloids could largely be the result of E+ tall fescue litter decomposition leaching the alkaloids into the soil. Omacini et al. [148] found that Lolium multiflorum infected with Epichloe endophyte decomposed more slowly than E- grass but will increase the speed of decomposition of different plant species nearby. This suggests a decrease in microbial activity on the E+ plant material [148].

Table 2. Epichloe endophyte infected grass influence on the accumulation of various compounds in the
Some specific differences in E+ tall fescue rhizodeposits and E- tall fescue rhizodeposits have been found. One study saw an increase in carbohydrates and organic carbon in the

E+ rhizodeposits than in the E- rhizodeposits [149]. Another study found higher amounts of phenolics in E+ root exudates. This could be due to greater phosphorus uptake by E+ tall fescue than E- tall fescue [150]. It must also be noted that the grass species and genotype can have a large impact on rhizodeposition [151]. Studies looking at the effect of grass endophytes on soil composition were the first to suggest that the soil microbiome was impacted by the endophyte. Studies dating back to the 1990s identified that tall fescue endophyte infection had an effect on levels of C and $\mathrm{N}$ in the soil [152]. Endophyte infected tall fescue (E+) have been shown to have differing effects on soil temperature, structure, nutrient levels, etc... Hosseini et al. [153] looked at the endophyte effect on soil structure stability using high energy moisture characteristic (HEMC) for quantification. They found that E+ tall fescue was correlated with increased soil organic carbon, increased stability ratio, and increased stable macropores [153]. Soil organic matter and hot-water soil carbohydrates were also increased which improves aggregate stability. These changes are possibly due to the endophytic fungus in the tall fescue plant changing the chemical makeup of its root exudates. This is interesting since the endophyte in the shoots must have such internal effects in the plant to act on the roots to the point that the physical qualities of the surrounding soil are impacted. Another study sought to identify the soil C fractions in infected tall fescue soil and uninfected tall fescue soil. Since there has been evidence that infected tall fescue leads to higher levels of $C$ sequestration, it was hypothesized that $\mathrm{E}+$ tall fescue would have higher $\mathrm{C}$ fractions. $\mathrm{C}$ sequestration is the ability of the soil to fix atmospheric $\mathrm{C}$. This provides important environmental effects as well as providing an essential nutrient to the plant and soil microorganisms. Handayani et al. [154] looked at $C$ levels in the two tall fescue systems over the course of four years. They took data on microbial biomass, particulate organic matter $\mathrm{C}$, microbial biomass $\mathrm{C}$, mineralizable $\mathrm{C}$, and $\mathrm{C}$ in micro and macro aggregates. They found that microbial biomass $\mathrm{C}$ and mineralizable $\mathrm{C}$ were the most sensitive indicators. Microbial biomass C (C contained within the microbes in the soil) was higher in E+ fields in shallow soil $(0-15 \mathrm{~cm})$ but did not differ at deeper depths. Mineralizable C (C available to the plant) was lower in E+ fields at both depths. These results suggest that the $C$ in the E+ soil was less labile than the $C$ in the E- soil. Microaggregates showed less $\mathrm{C}$ in infected tall fescue soil than in the uninfected field. 
Leaf material in the soil may have a differing effect on the soil microbiome than living roots. Franzluebbers et al. [147] conducted a study that looked at the effect of leaf material in soil long term and short term. They found that in the period of 32 days $\mathrm{E}+$ material resulted in decreased $\mathrm{C}$ mineralization and a decrease in microbial biomass $\mathrm{C}$. This is consistent with studies conducted with living plants. However, they did find that mineralizable $\mathrm{N}$ increased as well as

\begin{tabular}{|l|l|l|}
\hline Soil Component & E+ Effect & Reference \\
\hline Organic C & Increased & {$[149,153]$} \\
\hline Carbohydrates & Increased & {$[149]$} \\
\hline Phenols & Increased & {$[150]$} \\
\hline Organic Matter & Increased & {$[153]$} \\
\hline Microbial Biomass C & Mixed Results & {$[147,154]$} \\
\hline Mineralizable C & Decreased & {$[147,154]$} \\
\hline Microbial Biomass N & Increased & {$[147]$} \\
\hline Mineralizable N & Increased & {$[147]$} \\
\hline
\end{tabular}
microbial biomass $\mathrm{N}$ in the $\mathrm{E}+$ leaf material soil. These changes may be due to the phenolic compounds that are released from the leaves as they decompose [155]. In the longer-term study, they found an accumulation of $\mathrm{C}$ and $\mathrm{N}$ in the soil. Slower decomposition of litter can lead to $\mathrm{C}$ and $\mathrm{N}$ accumulation in the soil over time. When evaluating potential mineralizable $\mathrm{C}$ and $\mathrm{N}$ in the long term, they found a $5 \%$ decrease in mineralizable $\mathrm{C}$ in the infected leaf tissue soil. However, there was no change for potentially mineralizable N. Measurements of ergot alkaloid levels in

both E- and E+ soils were taken, and it was found that the soil that had E+ tall fescue growth for many years had 2.7 times more ergot alkaloid than the E- plots. The release and accumulation of the various compounds that are released from infected tall fescue as it decays influences the soil microbiome and the nutrients in the soil. These effects could be long lasting or short-lived. The mechanisms underlying how endophytes influence these processes, how this changes access to sparingly soluble soil $\mathrm{P}$, and how it might vary with endophyte strain or differences in soil $\mathrm{P}$ speciation and availability are still not known. Insight into the soil composition under E+ infected grasses can provide a starting point for evaluating microbial changes.

\section{Microbiome changes in response to stress}

As discussed above, the rhizosphere of a plant may change under abiotic stress conditions such as drought, flood, and salt pressure. The way that the microbiome changes will vary significantly from one grass to another as well as from one environment to another. For instance, drought stress has been found to negatively impact almost every part of the plant-rhizosphere ecosystem. This is expected as a decrease in moisture can lead to cell lysis and death in microbes. Additionally, under drought stress plants will decrease root biomass development and exudation which will lead to less nutrient supply for the microbiome [156]. Naylor et al. [157] investigated the root microbiome reaction to drought stress across 18 different grass species. They used $16 \mathrm{~S}$ rRNA gene sequencing and determined that microbial shifts under drought conditions were conserved across all species studied with actinobacteria being enriched. This enrichment could be due to cell wall component changes [157]. Furthermore, this drought tolerance in plants has strongly been linked to 'symbiogenics' or 'symbiosis-altered genetic expression' where certain microbial species colonize plant roots and confer drought resistance [158].

Nutrient stress is another abiotic stressor that may negatively impact the microbes that live in the soil. Generally, under decreased nutrient intake plants will have fewer root exudates released and therefore the microbiome will have less nutrients to scavenge as well [159]. While there is very little research that has studied changes in grass microbiomes under abiotic stressors, it has been documented that a robust microbial community is associated with abiotic stress tolerance in a variety of crop species [160]. Likely this is the case for grass species as well. For example, under most stressors' plants will produce ethylene which will eventually lead to senescence. The presence of any 1aminocyclopropane-1-carboxylic acid (ACC) deaminase-producing bacteria will decrease the ethylene levels and therefore decrease damage to the plant [161].

Much like with abiotic stresses, microbe response to biotic stresses is mixed. Once again little research has been done with grass species, but other studies in different plant species have found some interesting results. In cotton that 
was diseased with Verticillium, it was found that beneficial bacteria and fungi were greatly reduced and saprophytic fungi were increased [162]. Similarly, aphid infestation of the aerial parts of pepper plants led to root exudation composition changes to recruit bacteria that aided in aphid susceptibility [163]. Once again, enrichment with certain microbes can enhance plant resistance to pathogens but this may not occur under natural systems. In another study, a microbial-rich compost applied to tomato plants increased resistance to vascular wilt pathogens [164]. In a recent study, improved and balanced macro (calcium, magnesium) and micro (zinc)-nutrient content in the plant has also been attributed to the microbial population (applied as bio-inoculum) in iron-rich soil [165]. Furthermore, a complex trophic level dynamic was reported at $0-5 \mathrm{~cm}$ soil depth where soil native microbes and applied exogenous microbes coinhabited and improved soil nutrient cycling [166]. In soil, phosphorus is one of the major limited nutrients due to fixation in organo-mineral complex ( $\mathrm{Fe}$ and $\mathrm{Al}$ complexes in acid soil and $\mathrm{Ca}$ complex in alkaline soil), thus, severely limiting the bioavailability of soil $\mathrm{P}$ in soil solution for plant roots [167-170]. Soils with low nutrient content is characterized by lower soil microbial biomass and slower soil enzymatic release due to scant soil substrate [171]. Soil P release is a combined action of plant roots (changes in root architecture) and soil microorganisms (mycorrhizal activity, enzyme secretion and organic acid production) [110,172].

\section{Microbiome changes due to endophyte infection}

It is well established that Epichloe endophyte has some effect on soil nutrients and structure that may affect the bacterial makeup of the surrounding soil. There has been some evidence that alkaloids produced by endophytes may positively affect bacteria present in the phyllosphere. Roberts et al. [173] found that loline alkaloids in fescue encourage the selection of epiphytic bacteria in the aerial parts of the plant. This suggests that the different alkaloids may also enrich the bacteria in the soil. A follow-up study conducted by Roberts et al. [174] looked at the loline effect in the soil microbiome of infected tall fescue. They found that the loline-catabolizing bacteria significantly increased in just one week in the E+ tall fescue microbiome as opposed to the non-loline catabolizing bacteria. The loline-catabolizing bacteria did not increase significantly in the E- tall fescue. Interestingly, they also found that the E+ tall fescue had greater diversity within the microbiome overall. Shannon's diversity index numbers revealed that the E+ tall fescue had a $\mathrm{H}^{\prime}$ value of 4.02 compared to the E- tall fescue's $\mathrm{H}^{\prime}$ value of 3.07, indicating greater bacterial diversity. This study provides evidence that E+ tall fescue could positively impact the bacteria makeup of the microbiome in its soil [174]. However, there has also been evidence that Epichloe infected tall fescue consistently measures less qCO2, which is the rate of mineralizable $\mathrm{C}$ per microbial biomass $\mathrm{C}$. This suggests that there is a lower diversity of microorganisms that results in a lower soil metabolism [175].

Further investigation into tall fescue's endophyte effect on bacteria in the makeup in the microbiome has yielded some interesting results. One study looked at the difference in makeup between Eubacteria subdivisions including alpha, beta, gamma, delta, high G + C gram-positive bacteria, Cytophaga-Flavobacteria and Planctomycetes. It was found that in clay loam soil, E+ tall fescue had a suppressing effect on archaea, high $\mathrm{G}+\mathrm{C}$ gram-positive bacteria, deltaproteobacteria, and Planctomycetes [176]. Despite these decreases in soil bacteria, it was found that soil C did not change compared to E- tall fescue populations in the short term suggesting that the effect was not powerful enough to disturb soil nutrient cycling. Gram-positive bacteria were to be reduced by E+ tall fescue in several experiments. Buyer et al. [177] found that gram-positive bacteria was reduced in E+ tall fescue soil over 60 weeks. Gram-positive bacteria contain common genera of Cocci and Bacilli. Gram-positive bacteria are commonly found in the soil and can serve many purposes. While they can be pathogenic, there is also evidence of them serving as PGPBs [178]. Mahmud et al. [179] found that there were high levels of planctomycetes, proteobacteria, and acidobacteria in E+ tall fescue soil. Proteobacteria and acidobacteria ratio (P/A) indicate soil nutrient richness with high $\mathrm{P} / \mathrm{A}$ indicating rich soil. E- soil had a higher P/A ratio and E+ had a lower ratio. Despite this, the E+ tall fescue performed better than the E- tall fescue 
suggesting the endophyte makes up for any nutrient loss. Indeed, it was found that the E+ grasses had higher available $P$ in the soil.

Bacterial makeup may change under stress conditions in E+ soil as well. One study found that the root and rhizosphere bacterial community diversity decreased under drought conditions in E. gansuensis infected drunken horse grass soil [180]. This is in addition to the already lowered root colonizing bacterial diversity seen in the E+ soil. More research has been done on manipulating the bacterial community under stress for plant productivity improvement. Endophyte infected and uninfected drunken horse grass had better rates of seed germination under salt stress when PGPR was added. Endophyte infection alone improved plant germination under salt stress so this effect may be compounded with PGPR [181]. This is likely due to superoxide dismutase, peroxidase, and catalase activity being increased. These enzymes are protectants of the plant cells from oxidative stress. Malondialdehyde, an indicator of oxidative damage, was also decreased in E+ soil. This suggests that the endophyte along with PGPR provide protections from the oxidative stress that high salt content could induce. The endophyte may also promote PGP bacteria under normal and drought conditions. A study carried out in 2016 found that E+ seedlings recovered faster from drought stress than E+ seeds that had been surface-sterilized and E- seeds. The E+ seeds had higher populations of PGP bacteria compared to E- suggesting that the endophyte promotes this association [182]. Bacterial changes are likely due to changes in the root exudates that are modulated by the Epichloe endophyte. Changes in volatile organic compounds, flavonoids, and phenolic compounds have been shown under endophyte infection [183].

Many plants have mutualistic relationships with below-ground fungi called arbuscular mycorrhizal fungi (AMF). They help provide the plant with nutrients and can help with stressors such as drought and pathogens [184]. Some investigations into the effect of Epichloe infected grasses on AMF find it greatly reduced. Interestingly, it has been found that neighbors of E+ grasses will have increased AMF infection. One mechanism by which this may occur is that the foliar endophytes require too many nutrients for the AMF to be sustained as well. The endophyte confers protections greater than that of the AMF in most cases making it likely that the plant would choose to put its resources towards it $[185,186]$. The change is likely due to endophyte-mediated changes to the rhizodeposits which change the soil composition. There are also conflicting studies that show Epichloe infection increased AMF colonizing the roots. Vignale et al. [187] researched the AMF with Epichloe fungi in vitro by itself and in vivo with association with B. auleticus. It was found that the endophyte exudates aided in AMF germination prior to root colonization whereas the E-controls had no effect [187]. Stress conditions could also influence the grass-endophyte-AMF relationship. Zhong et al. [188] found that $\mathrm{E}+$ drunken horse grass decreased AMF root colonization diversity under normal moisture conditions but increased AMF diversity under drought conditions. The mechanisms for this are unclear however it may be the grass allocating resources away from the endophyte when it is over-taxed. It appears that the 3-way association can work together to alleviate stress in the grass. Li et al. [189] found that E+perennial ryegrass with AMF colonization survived better under drought conditions by having increased P uptake, higher levels of photosynthesis, and osmoregulation. Similarly, Guo et al. [190] found that while both E+ perennial ryegrass and AMF colonized perennial ryegrass were more resistant to leaf spot, the combination of AMF and endophyte lead to the highest resistance. Low soil nutrients did not affect either fungi's ability to mitigate the pathogen. Increased 3-glucanase activity and jasmonic acid activity were found in the resistant grass. Similarly, Bastias et al, 2017 presented the idea that AMF can aid in plant defense through hormone signaling. This is called mycorrhiza-induced resistance and is thought to be mediated by JA. Epichloe enhancement of the JA pathway may help prompt this relationship with AMF that leads to increased pathogen resistance [83]. Whether AMF is being inhibited or enhanced, it is likely due to the root exudates produced by the grass-endophyte association. Similar to the research we have seen within the shoots of the plant, flavonoids, and phenolic compounds are produced in higher amounts in the roots when Epichloe infections are present [188]. Phenolic compounds are generally thought to be anti-fungal and anti-bacterial, however, there are some studies showing increases in phenol production in association with AMF [191]. In addition to AMF, other fungi are affected by endophyte status. It was found that endophyte-infected 
tall fescue microbiomes had an overall very diverse fungal population at the genus level. There also was a distinct shift from basidiomycetes to ascomycetes fungi from E- to E+ grass [179]. Overall, the diversity of microbes will help contribute to the resilience of the plant under stress conditions. The exact host-endophyte association may lead to specific differences in the flavonoids and phenols being produced that would affect below-ground microbes in different ways, which may lead to the conflicting reports we have found regarding fungi presence.

\section{Discussion and Conclusions}

In this review, we highlighted some of the major mechanisms by which cool-season grasses, Epichloe endophyte, and the rhizosphere work in harmony to mitigate abiotic and biotic stressors. This can be quite complex to untangle but there are a few underlying mechanistic takeaways. Epichloe endophytes function to protect their grass hosts under stress through a combination of toxic alkaloid production, increased production and changes to enzymatic and non-enzymatic antioxidants, precursors to JA production, increased production and changes to VOCs, increased production of osmoregulatory substances, and increased production of other substances with vital physiological effects such as amino acids and carbohydrates. The upregulation and changes in the production of these substances are most likely due to the endophyte causing gene expression changes in the plant. Research has shown that endophyte infection causes many genes to be up and downregulated [34,35]. Epichloe fungal endophytes and cool-season grasses have a long evolutionary history together in which they were able to develop these molecular communications. Their co-evolvement has resulted in a change from pathogen to mutualist. One of the mechanisms responsible for this change is the production of antioxidants. An antioxidant is a substance that inhibits oxidation. These are often enzymes that mitigate the effects of ROS. ROS are natural byproducts of basic physiological functions like photosynthesis and respiration. When ROS accumulates it causes damage at a cellular level. Antioxidants operate as part of the plant's immune system. They function to help identify and respond to stress [49]. The Epichloe endophyte increases antioxidant production within grasses which first operates to aid in mutualism and then aid in defense response. We see antioxidants playing an important role in defense against most abiotic and biotic stressors. Endophyte association also increases phenolic compounds in the plant, which are also associated with being an antioxidant and plant defense. Phenols are found in higher amounts not only in the shoots of E+ grass but also in the roots. In this way, they can have a direct effect on the soil microbiome. Another class of non-enzymatic antioxidants are flavonoids. These have also been shown to be produced in higher amounts in the shoots and roots of E+ grasses and can therefore also alter the microbial population [183]. Endophyte infection upregulates the production of other substances that have physiological implications such as amino acids and sugars [62,65]. We see this particularly under drought and salt stress where some of these substances have osmoregulatory properties. Amino acids also help with nutrient availability by changing the plant metabolism

Fig. 3. Diagram of proposed interactions between Epichloe endophytes, grass, stress and the microbiome. Grass infection with the endophyte leads to gene expression changes which alters the production of a host of different compounds. The endophyte produces alkaloids. Alkaloids and the protective compounds produced lead to better stress tolerance of the grass. The same compounds and alkaloids may also have an effect on root exudates secreted by the grass into the soil. This could impact the microorganims present there which has a feedback effect on the grass.

[62]. How the endophyte affects SA and JA pathways are somewhat unclear yet, but research has found that certain precursors to JA are produced in E+ grasses [82,83]. The increased production and changes to the production of VOCs can lead to host defense, communication, and phytohormone production [88]. In addition, differing VOCs are exuded by the roots of E+ grasses that would affect the microbiome [183]. Alkaloids can serve as antioxidants but their main 
protection in grasses is to be toxic to herbivores, including insects and mammals. The combination of all these factors leads to a much higher performing plant under stress conditions.

The changes that the endophyte induces in the soil microbiome are mixed. Studies have found conflicting information as to whether certain microbes are increased or decreased. The main takeaway from this is that every microbiome and E+ grass interaction is specific. Endophyte and host associations are very distinct in terms of

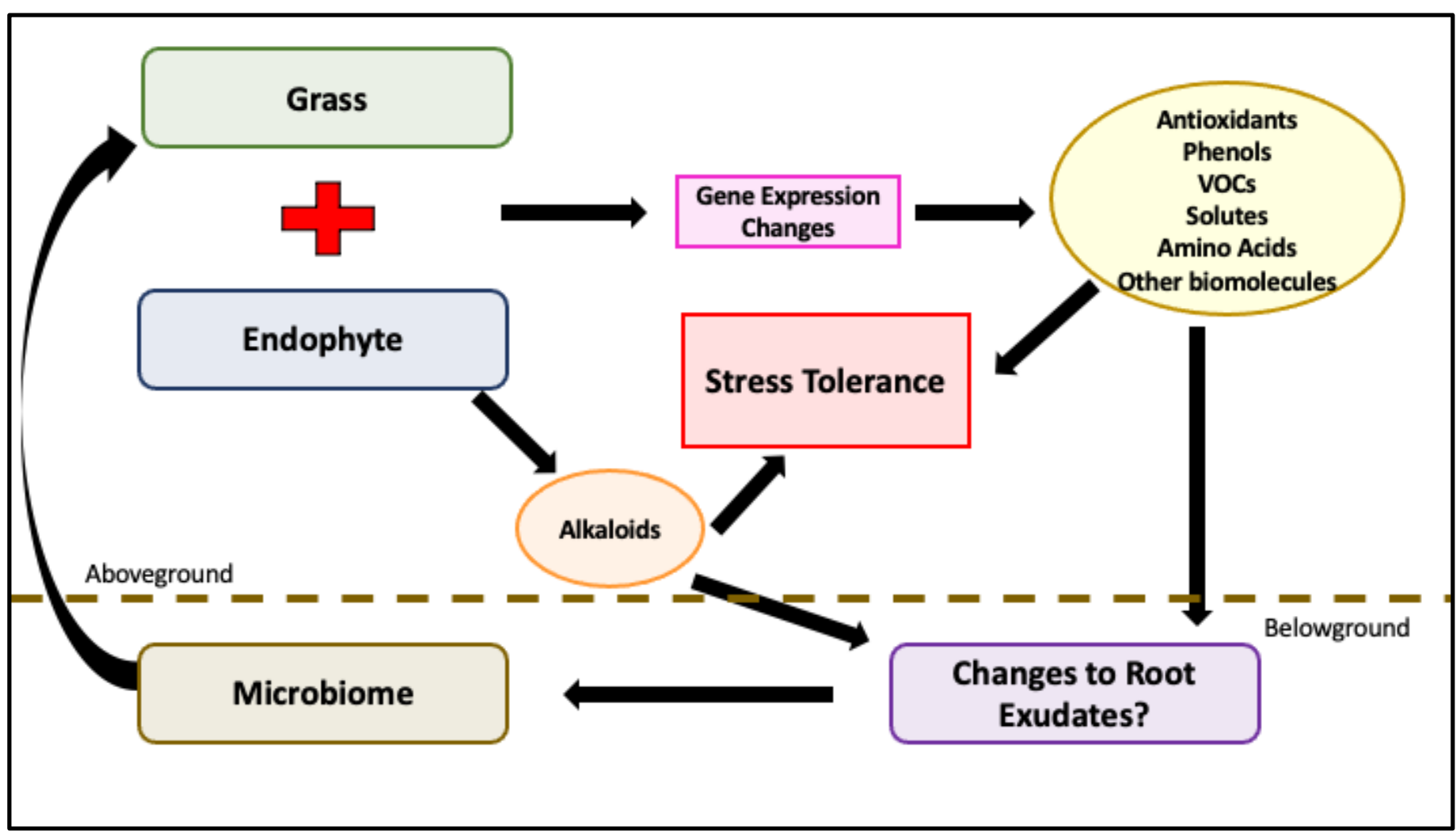

compatibility. The different interactions between each fungus and host likely change the ways in which root exudates are altered. In addition, microbiomes change drastically based on the environment. Taken together, it is impossible to make a blanket statement as to how Epichloe endophytes affect all microbes except to say that there is some effect. Another takeaway is that manipulation of the microbiome through PGP bacteria and AMF fungi will probably only strengthen the fitness of the E+ grass and certainly won't be detrimental.

These findings show that improved plant fitness goes far beyond just alkaloid production in E+ grasses. It also shows that the grass, endophyte, and microbiome is a very complex system that cannot be easily generalized. But still, these findings have implications for natural and agricultural systems that utilize the grass. It gives us an understanding of what goes into increasing grass performance under stress. It also gives us actionable items as far as biofertilization with PGP bacteria. More research into the molecular communication of this complex relationship to fully elucidate the mechanisms by which these organisms operate would provide even better insight that could potentially be utilized for agricultural systems.

Author Contributions: Conceptualization, Kendall Lee and Ali Missaoui. writing-original draft preparation, Kendall Lee and Kishan Mahmud; writing - Kendall Lee, Ali Missaoui, Kishan Mahmud, research- Kendall Lee, Kishan Mahmud, Holly Presley, Marin Lonnee. All authors have read and agreed to the published version of the manuscript.

Funding:

Cultivar development and research fund, Innovation Gateway, the University of Georgia

Conflicts of Interest: The authors declare no conflict of interest. 


\section{References}

1. Hanson, J.; Cantrell, J.; Proud, J.; Debouck, D.; Cuervo, M.; Schultze-Kraft, R.; Jorge, A. Forage: grass. 2021.

2. Sanderson, M.; Jolley, L.W.; Dobrowolski, J. Pasture and hayland in the USA: Land resources, conservation practices, and ecosystem services. 2012; pp. 25-40.

3. Wilkins, P.W.; Humphreys, M.O. Progress in breeding perennial forage grasses for temperate agriculture. The Journal of Agricultural Science 2003, 140, 129-150.

4. Moser, L.E.; Hoveland, C.S. 1996.

5. Leuchtmann, A. Systematics, distribution, and host specificity of grass endophytes. Natural Toxins 1993, 1, 150-162, doi:https://doi.org/10.1002/nt.2620010303.

6. Young, C.A.; Charlton, N.D.; Takach, J.E.; Swoboda, G.A.; Trammell, M.A.; Huhman, D.V.; Hopkins, A.A. Characterization of Epichloe coenophiala within the US: are all tall fescue endophytes created equal? Front Chem 2014, 2, doi:ARTN 95

10.3389/fchem.2014.00095.

7. Faeth, S.H.; Hamilton, C.E. Does An Asexual Endophyte Symbiont Alter Life Stage and Long-Term Survival in a Perennial Host Grass? Microbial Ecology 2006, 52, 748-755, doi:10.1007/s00248-006-9123-z.

8. Easton, H.S. Grasses and Neotyphodium endophytes: co-adaptation and adaptive breeding. Euphytica 2007, 154, 295-306, doi:10.1007/s10681-006-9187-3.

9. Schardl, C.L.; Craven, K.D.; Speakman, S.; Stromberg, A.; Lindstrom, A.; Yoshida, R. A novel test for hostsymbiont codivergence indicates ancient origin of fungal endophytes in grasses. Syst Biol 2008, 57, 483-498, doi:10.1080/10635150802172184.

10. Frank, S.A. Genetics of mutualism: the evolution of altruism between species. J Theor Biol 1994, 170, 393-400, doi:10.1006/jtbi.1994.1200.

11. Tsai, H.F.; Liu, J.S.; Staben, C.; Christensen, M.J.; Latch, G.C.; Siegel, M.R.; Schardl, C.L. Evolutionary diversification of fungal endophytes of tall fescue grass by hybridization with Epichloë species. Proc Natl Acad Sci U S A 1994, 91, 2542-2546, doi:10.1073/pnas.91.7.2542.

12. Moon, C.D.; Craven, K.D.; Leuchtmann, A.; Clement, S.L.; Schardl, C.L. Prevalence of interspecific hybrids amongst asexual fungal endophytes of grasses. Mol Ecol 2004, 13, 1455-1467, doi:10.1111/j.1365294X.2004.02138.x.

13. Saikkonen, K.; Young, C.A.; Helander, M.; Schardl, C.L. Endophytic Epichloë species and their grass hosts: from evolution to applications. Plant Mol Biol 2016, 90, 665-675, doi:10.1007/s11103-015-0399-6.

14. Schardl, C.L.; Leuchtmann, A.; Chung, K.R.; Siegel, M.R.; Penny, D. Coevolution by Common Descent of Fungal Symbionts Grass Hosts. 1998.

15. Bacon, C.W.; Siegel, M.R. Endophyte Parasitism of Tall Fescue. Journal of Production Agriculture 1988, 1, 45-55, doi:https://doi.org/10.2134/jpa1988.0045.

16. Young, C.A.; Felitti, S.; Shields, K.; Spangenberg, G.; Johnson, R.D.; Bryan, G.T.; Saikia, S.; Scott, B. A complex gene cluster for indole-diterpene biosynthesis in the grass endophyte Neotyphodium lolii. Fungal Genetics and Biology 2006, 43, 679-693, doi:https://doi.org/10.1016/j.fgb.2006.04.004.

17. Hettiarachchige, I.K.; Elkins, A.C.; Reddy, P.; Mann, R.C.; Guthridge, K.M.; Sawbridge, T.I.; Forster, J.W.; Spangenberg, G.C. Genetic modification of asexual Epichloë endophytes with the perA gene for peramine biosynthesis. Molecular Genetics and Genomics 2019, 294, 315-328, doi:10.1007/s00438-018-1510-x.

18. Young, C.A.; Schardl, C.L.; Panaccione, D.G.; Florea, S.; Takach, J.E.; Charlton, N.D.; Moore, N.; Webb, J.S.; Jaromczyk, J. Genetics, genomics and evolution of ergot alkaloid diversity. Toxins (Basel) 2015, 7, 1273-1302, doi:10.3390/toxins7041273. 
19. Xia, C.; Li, N.; Zhang, Y.; Li, C.; Zhang, X.; Nan, Z. Role of Epichloë Endophytes in Defense Responses of Cool-Season Grasses to Pathogens: A Review. Plant Disease 2018, 102, 2061-2073, doi:10.1094/pdis-05-18-0762fe.

20. Freitas, P.P.; Hampton, J.G.; Rolston, M.P.; Glare, T.R.; Miller, P.P.; Card, S.D. A Tale of Two Grass Species: Temperature Affects the Symbiosis of a Mutualistic Epichloë Endophyte in Both Tall Fescue and Perennial Ryegrass. Front Plant Sci 2020, 11, doi:10.3389/fpls.2020.00530.

21. Bouton, J.H.; Gates, R.N.; Belesky, D.P.; Owsley, M. Yield and Persistence of Tall Fescue in the Southeastern Coastal Plain after Removal of Its Endophyte. Agron J 1993, 85, 52-55, doi:https://doi.org/10.2134/agronj1993.00021962008500010011x.

22. Saikkonen, K.; Young, C.A.; Helander, M.; Schardl, C.L. Endophytic Epichloë species and their grass hosts: from evolution to applications. Plant Mol Biol 2016, 90, 665-675, doi:10.1007/s11103-015-0399-6.

23. Malinowski, D.P.; Belesky, D.P. Adaptations of Endophyte-Infected Cool-Season Grasses to Environmental Stresses: Mechanisms of Drought and Mineral Stress Tolerance. Crop Sci 2000, 40, 923-940, doi:https://doi.org/10.2135/cropsci2000.404923x.

24. West, C.P.; Izekor, E.; Turner, K.E.; Elmi, A.A. Endophyte Effects on Growth and Persistence of Tall Fescue along a Water-Supply Gradient. Agron J 1993, 85, 264-270, doi:https://doi.org/10.2134/agronj1993.00021962008500020019x.

25. Hume, D.E.; Cooper, B.; Panckhurst, K. The role of endophyte in determining the persistence and productivity of ryegrass, tall fescue and meadow fescue in Northland. 2009.

26. Eaton, C.J.; Cox, M.P.; Scott, B. What triggers grass endophytes to switch from mutualism to pathogenism? Plant Sci 2011, 180, 190-195, doi:10.1016/j.plantsci.2010.10.002.

27. Malinowski, D.; Belesky, D. Epichloë (formerly Neotyphodium) fungal endophytes increase adaptation of cool-season perennial grasses to environmental stresses. Acta Agrobotanica 2019, 72, doi:10.5586/aa.1767.

28. Tanaka, A.; Christensen, M.J.; Takemoto, D.; Park, P.; Scott, B. Reactive Oxygen Species Play a Role in Regulating a Fungus-Perennial Ryegrass Mutualistic Interaction. The Plant Cell 2006, 18, 1052-1066, doi:10.1105/tpc.105.039263.

29. Pimentel, M.R.; Molina, G.; Dionísio, A.P.; Maróstica Junior, M.R.; Pastore, G.M. The Use of Endophytes to Obtain Bioactive Compounds and Their Application in Biotransformation Process. Biotechnology Research International 2011, 2011, 576286, doi:10.4061/2011/576286.

30. Pan, F.; Hou, K.; Gao, F.; Hu, B.; Chen, Q.; Wu, W. Peimisine and peiminine production by endophytic fungus Fusarium sp. isolated from Fritillaria unibracteata var. wabensis. Phytomedicine 2014, 21, 1104-1109, doi:10.1016/j.phymed.2014.04.010.

31. Nagabhyru, P.; Dinkins, R.D.; Schardl, C.L. Transcriptomics of Epichloë-Grass Symbioses in Host Vegetative and Reproductive Stages. Molecular Plant-Microbe Interactions ${ }^{\circledR}$ 2018, 32, 194-207, doi:10.1094/MPMI-10-170251-R.

32. Kayano, Y.; Tanaka, A.; Takemoto, D. Two closely related Rho GTPases, Cdc42 and RacA, of the en-dophytic fungus Epichloë festucae have contrasting roles for ROS production and symbiotic infection synchronized with the host plant. PLOS Pathogens 2018, 14, e1006840, doi:10.1371/journal.ppat.1006840.

33. Green, K.A.; Becker, Y.; Fitzsimons, H.L.; Scott, B. An Epichloë festucae homologue of MOB3, a component of the STRIPAK complex, is required for the establishment of a mutualistic symbiotic interaction with Lolium perenne. Molecular Plant Pathology 2016, 17, 1480-1492, doi:https://doi.org/10.1111/mpp.12443.

34. Eaton, C.J.; Dupont, P.-Y.; Solomon, P.; Clayton, W.; Scott, B.; Cox, M.P. A Core Gene Set Describes the Molecular Basis of Mutualism and Antagonism in Epichloë spp. Molecular Plant-Microbe Interactions ${ }^{\circledR}$ 2014, 28, 218-231, doi:10.1094/MPMI-09-14-0293-FI. 
35. Schmid, J.; Day, R.; Zhang, N.; Dupont, P.-Y.; Cox, M.P.; Schardl, C.L.; Minards, N.; Truglio, M.; Moore, N.; Harris, D.R.; et al. Host Tissue Environment Directs Activities of an Epichloë Endophyte, While It Induces Systemic Hormone and Defense Responses in Its Native Perennial Ryegrass Host. Molecular Plant-Microbe Interactions ${ }^{\circledR}$ 2016, 30, 138-149, doi:10.1094/MPMI-10-16-0215-R.

36. Helander, M.; Phillips, T.; Faeth, S.H.; Bush, L.P.; McCulley, R.; Saloniemi, I.; Saikkonen, K. Alkaloid Quantities in Endophyte-Infected Tall Fescue are Affected by the Plant-Fungus Combination and Environment. Journal of Chemical Ecology 2016, 42, 118-126, doi:10.1007/s10886-016-0667-1.

37. Hennessy, L.M.; Popay, A.J.; Finch, S.C.; Clearwater, M.J.; Cave, V.M. Temperature and Plant Genotype Alter Alkaloid Concentrations in Ryegrass Infected with an Epichloë Endophyte and This Affects an Insect Herbivore. Front Plant Sci 2016, 7, doi:10.3389/fpls.2016.01097.

38. Rasmussen, S.; Parsons, A.J.; Bassett, S.; Christensen, M.J.; Hume, D.E.; Johnson, L.J.; Johnson, R.D.; Simpson, W.R.; Stacke, C.; Voisey, C.R.; et al. High nitrogen supply and carbohydrate content reduce fungal endophyte and alkaloid concentration in Lolium perenne. New Phytol 2007, 173, 787-797,

doi:https://doi.org/10.1111/j.1469-8137.2006.01960.x.

39. Hill, N.S. Ecological Relationships of Balansiae-Infected Graminoids. In Biotechnology of Endophytic Fungi of Grasses, Bacon, C.W., White, J., Eds.; 1994.

40. Faeth, S.; Helander, M.; Saikkonen, K. Asexual Neotyphodium endophytes in a native grass reduce competitive abilities. Ecology Letters 2004, 7, 304-313, doi:10.1111/j.1461-0248.2004.00578.x.

41. Cheplick, G.P. Costs of fungal endophyte infection in Lolium perenne genotypes from Eurasia and North Africa under extreme resource limitation. Environmental and Experimental Botany 2007, 60, 202-210.

42. Bacon, C.W. Abiotic stress tolerances (moisture, nutrients) and photosynthesis in endophyte-infected tall fescue. Agriculture, Ecosystems E Environment 1993, 44, 123-141, doi:https://doi.org/10.1016/0167-8809(93)90042$\underline{N}$.

43. LATCH, G.C.M.; CHRISTENSEN, M.J. Artificial infection of grasses with endophytes. Annals of Applied Biology 1985, 107, 17-24, doi:https://doi.org/10.1111/j.1744-7348.1985.tb01543.x.

44. De Battista, J.; Altier, N.; Galdames, D.R.; Dall'Agnol, M. Significance of Endophyte Toxicosis and Current Practices in Dealing with the Problem in South America. In Neotyphodium/Grass Interactions, Bacon, C.W., Hill, N.S., Eds.; Springer US: Boston, MA, 1997; pp. 383-388.

45. De Battista, J.P.; Bouton, J.H.; Bacon, C.W.; Siegel, M.R. Rhizome and Herbage Production of EndophyteRemoved Tall Fescue Clones and Populations. Agron J 1990, 82, 651-654, doi:https://doi.org/10.2134/agronj1990.00021962008200040001x.

46. ELMI, A.A.; WEST, C.P. Endophyte infection effects on stomatal conductance, osmotic adjustment and drought recovery of tall fescue. New Phytol 1995, 131, 61-67, doi:https://doi.org/10.1111/j.14698137.1995.tb03055.x.

47. Nagabhyru, P.; Dinkins, R.D.; Wood, C.L.; Bacon, C.W.; Schardl, C.L. Tall fescue endophyte effects on tolerance to water-deficit stress. BMC Plant Biology 2013, 13, 127, doi:10.1186/1471-2229-13-127.

48. Dupont, P.-Y.; Eaton, C.J.; Wargent, J.J.; Fechtner, S.; Solomon, P.; Schmid, J.; Day, R.C.; Scott, B.; Cox, M.P. Fungal endophyte infection of ryegrass reprograms host metabolism and alters development. New Phytol 2015, 208, 1227-1240, doi:https://doi.org/10.1111/nph.13614.

49. Sarker, U.; Oba, S. Catalase, superoxide dismutase and ascorbate-glutathione cycle enzymes confer drought tolerance of Amaranthus tricolor. Scientific reports 2018, 8, 16496-16496, doi:10.1038/s41598-018-34944-0.

50. Reza Sabzalian, M.; Mirlohi, A. Neotyphodium endophytes trigger salt resistance in tall and meadow fescues. Journal of Plant Nutrition and Soil Science 2010, 173, 952-957, doi:https://doi.org/10.1002/jpln.200900345. 
51. Wang, J.; Tian, P.; Christensen, M.J.; Zhang, X.; Li, C.; Nan, Z. Effect of Epichloë gansuensis endophyte on the activity of enzymes of nitrogen metabolism, nitrogen use efficiency and photosynthetic ability of Achnatherum inebrians under various $\mathrm{NaCl}$ concentrations. Plant Soil 2019, 435, 57-68, doi:10.1007/s11104018-3868-2.

52. Song, M.; Chai, Q.; Li, X.; Yao, X.; Li, C.; Christensen, M.J.; Nan, Z. An asexual Epichloë endophyte modifies the nutrient stoichiometry of wild barley (Hordeum brevisubulatum) under salt stress. Plant Soil 2015, 387, 153-165, doi:10.1007/s11104-014-2289-0.

53. Chen, T.; Johnson, R.; Chen, S.; Lv, H.; Zhou, J.; Li, C. Infection by the fungal endophyte Epichloë bromicola enhances the tolerance of wild barley (Hordeum brevisubulatum) to salt and alkali stresses. Plant Soil 2018, 428, 353-370, doi:10.1007/s11104-018-3643-4.

54. Yang, W.-J.; Rich, P.J.; Axtell, J.D.; Wood, K.V.; Bonham, C.C.; Ejeta, G.; Mickelbart, M.V.; Rhodes, D. Genotypic Variation for Glycinebetaine in Sorghum. Crop Sci 2003, 43, 162-169, doi:https://doi.org/10.2135/cropsci2003.1620.

55. Campbell, J.; Zhang, H.; Giroux, M.J.; Feiz, L.; Jin, Y.; Wang, M.; Chen, X.; Huang, L. A mutagenesis-derived broad-spectrum disease resistance locus in wheat. TAG. Theoretical and applied genetics. Theoretische und angewandte Genetik 2012, 125, 391-404, doi:10.1007/s00122-012-1841-7.

56. Ren, A.; Gao, Y.; Zhang, L.; Xie, F. Effects of cadmium on growth parameters of endophyte-infected endophyte-free ryegrass. Journal of Plant Nutrition and Soil Science 2006, 169, 857-860, doi:https://doi.org/10.1002/jpln.200520543.

57. Monnet, F.; Vaillant, N.; Hitmi, A.; Coudret, A.; Sallanon, H. Endophytic Neotyphodium lolii induced tolerance to Zn stress in Lolium perenne. Physiologia Plantarum 2001, 113, 557-563, doi:https://doi.org/10.1034/j.1399-3054.2001.1130415.x.

58. Brisson, L.F.; Tenhaken, R.; Lamb, C. Function of Oxidative Cross-Linking of Cell Wall Structural Proteins in Plant Disease Resistance. The Plant Cell 1994, 6, 1703-1712, doi:10.1105/tpc.6.12.1703.

59. Wang, J.; Nan, Z.; Christensen, M.J.; Zhang, X.; Tian, P.; Zhang, Z.; Niu, X.; Gao, P.; Chen, T.; Ma, L. Effect of Epichloë gansuensis Endophyte on the Nitrogen Metabolism, Nitrogen Use Efficiency, and Stoichiometry of Achnatherum inebrians under Nitrogen Limitation. J Agr Food Chem 2018, 66, 4022-4031, doi:10.1021/acs.jafc.7b06158.

60. Wang, J.; Nan, Z.; Christensen, M.J.; Li, C. Glucose-6-phosphate dehydrogenase plays a vital role in Achnatherum inebrians plants host to Epichloë gansuensis by improving growth under nitrogen deficiency. Plant Soil 2018, 430, 37-48, doi:10.1007/s11104-018-3710-x.

61. Li, X.; Ren, A.; Han, R.; Yin, L.; Wei, M.; Gao, Y. Endophyte-Mediated Effects on the Growth and Physiology of Achnatherum sibiricum Are Conditional on Both N and P Availability. PLOS ONE 2012, 7, e48010, doi:10.1371/journal.pone.0048010.

62. Liu, Y.; Hou, W.; Jin, J.; Christensen, M.J.; Gu, L.; Cheng, C.; Wang, J. Epichloë gansuensis Increases the Tolerance of Achnatherum inebrians to Low-P Stress by Modulating Amino Acids Metabolism and Phosphorus Utilization Efficiency. Journal of Fungi 2021, 7, doi:10.3390/jof7050390.

63. Heineck, G.C.; Watkins, E.; Ehlke, N.J. The Fungal Endophyte Epichloë festucae var. lolii Does Not Improve the Freezing Tolerance of Perennial Ryegrass. Crop Sci 2018, 58, 1788-1800, doi:https://doi.org/10.2135/cropsci2017.12.0731.

64. Chen, N.; He, R.; Chai, Q.; Li, C.; Nan, Z. Transcriptomic analyses giving insights into molecular regulation mechanisms involved in cold tolerance by Epichloë endophyte in seed germination of Achnatherum inebrians. Plant Growth Regulation 2016, 80, 367-375, doi:10.1007/s10725-016-0177-8. 
65. De Santis, A.; Landi, P.; Genchi, G. Changes of mitochondrial properties in maize seedlings associated with selection for germination at low temperature. Fatty acid composition, cytochrome c oxidase, and adenine nucleotide translocase activities. Plant physiology 1999, 119, 743-754, doi:10.1104/pp.119.2.743.

66. Zhou, L.; Li, C.; Zhang, X.; Johnson, R.; Bao, G.; Yao, X.; Chai, Q. Effects of cold shocked Epichloë infected Festuca sinensis on ergot alkaloid accumulation. Fungal Ecol 2015, 14, 99-104,

doi:https://doi.org/10.1016/j.funeco.2014.12.006.

67. Arachevaleta, M.; Bacon, C.W.; Hoveland, C.S.; Radcliffe, D.E. Effect of the Tall Fescue Endophyte on Plant Response to Environmental Stress. Agron J 1989, 81, 83-90, doi:https://doi.org/10.2134/agronj1989.00021962008100010015x.

68. Adams, A.E.; Kazenel, M.R.; Rudgers, J.A. Does a foliar endophyte improve plant fitness under flooding? Plant Ecology 2017, 218, 711-723, doi:10.1007/s11258-017-0723-0.

69. Song, M.; Li, X.; Saikkonen, K.; Li, C.; Nan, Z. An asexual Epichloë endophyte enhances waterlogging tolerance of Hordeum brevisubulatum. Fungal Ecol 2015, 13, 44-52,

doi:https://doi.org/10.1016/j.funeco.2014.07.004.

70. Wang, J.; Zhou, Y.; Lin, W.; Li, M.; Wang, M.; Wang, Z.; Kuang, Y.; Tian, P. Effect of an Epichloë endophyte on adaptability to water stress in Festuca sinensis. Fungal Ecol 2017, 30, 39-47,

doi:https://doi.org/10.1016/j.funeco.2017.08.005.

71. Chu-Chou, M.; Guo, B.; An, Z.Q.; Hendrix, J.W.; Ferriss, R.S.; Siegel, M.R.; Dougherty, C.T.; Burrus, P.B. Suppression of mycorrhizal fungi in fescue by the acremonium coenophialum endophyte. Soil Biology and Biochemistry 1992, 24, 633-637, doi:https://doi.org/10.1016/0038-0717(92)90041-U.

72. Clarke, B.B.; White, J.F.; Hurley, R.H.; Torres, M.S.; Sun, S.; Huff, D.R. Endophyte-Mediated Suppression of Dollar Spot Disease in Fine Fescues. Plant Disease 2006, 90, 994-998, doi:10.1094/PD-90-0994.

73. Ambrose, K.V.; Belanger, F.C. SOLiD-SAGE of Endophyte-Infected Red Fescue Reveals Numerous Effects on Host Transcriptome and an Abundance of Highly Expressed Fungal Secreted Proteins. PLOS ONE 2012, 7, e53214, doi:10.1371/journal.pone.0053214.

74. Ma, M.; Christensen, M.J.; Nan, Z. Effects of the endophyte Epichloë festucae var. lolii of perennial ryegrass (Lolium perenne) on indicators of oxidative stress from pathogenic fungi during seed germination and seedling growth. European Journal of Plant Pathology 2015, 141, 571-583, doi:10.1007/s10658-014-0563-x.

75. Schmidt, D.; Scehovic, J. Results of one trial examining the influence of Acremonium uncinatum and leaf spot diseases on different chemical components and nutritive value of Festuca pratensis. Bulletin OILB SROP 1994, 17.

76. Ma Min-zhi, N.A.N.Z.-b. Effect of fungal endophytes against rust disease of perennial ryegrass (<i>Lolium perenne</i>) on growth and physiological indices. Acta Prataculturae Sinica 2011, 20, 150-156.

77. Perez, L.I.; Gundel, P.E.; Marrero, H.J.; Arzac, A.G.; Omacini, M. Symbiosis with systemic fungal endophytes promotes host escape from vector-borne disease. Oecologia 2017, 184, 237-245, doi:10.1007/s00442-017-3850-3.

78. Iannone, L.J.; Vignale, M.V.; Pinget, A.D.; Re, A.; Mc Cargo, P.D.; Novas, M.V. Seed-transmitted Epichloë sp. endophyte alleviates the negative effects of head smut of grasses (Ustilago bullata) on Bromus auleticus.

Fungal Ecol 2017, 29, 45-51, doi:https://doi.org/10.1016/j.funeco.2017.06.001.

79. Górzyńska, K.; Ryszka, P.; Anielska, T.; Turnau, K.; Lembicz, M. Effect of Epichloë typhina fungal endophyte on the diversity and incidence of other fungi in Puccinellia distans wild grass seeds. Flora 2017, 228, 60-64, doi:https://doi.org/10.1016/j.flora.2017.01.008.

80. Wang, X.; Qin, J.; Chen, W.; Zhou, Y.; Ren, A.; Gao, Y. Pathogen resistant advantage of endophyte-infected over endophyte-free Leymus chinensis is strengthened by pre-drought treatment. European Journal of Plant Pathology 2016, 144, 477-486, doi:10.1007/s10658-015-0788-3. 
81. Funnell-Harris, D.L.; Pedersen, J.F.; Sattler, S.E. Alteration in Lignin Biosynthesis Restricts Growth of Fusarium spp. in Brown Midrib Sorghum. Phytopathology® 2010, 100, 671-681, doi:10.1094/PHYTO-100-7-0671.

82. Johnson, L.J.; Johnson, R.D.; Schardl, C.L.; Panaccione, D.G. Identification of differentially expressed genes in the mutualistic association of tall fescue with Neotyphodium coenophialum. Physiological and Molecular Plant Pathology 2003, 63, 305-317, doi:https://doi.org/10.1016/j.pmpp.2004.04.001.

83. Bastias, D.A.; Martínez-Ghersa, M.A.; Ballaré, C.L.; Gundel, P.E. Epichloë Fungal Endophytes and Plant Defenses: Not Just Alkaloids. Trends in Plant Science 2017, 22, 939-948,

doi:https://doi.org/10.1016/j.tplants.2017.08.005.

84. Rasmussen, S.; Parsons, A.J.; Fraser, K.; Xue, H.; Newman, J.A. Metabolic Profiles of Lolium perenne Are Differentially Affected by Nitrogen Supply, Carbohydrate Content, and Fungal Endophyte Infection Plant Physiology 2008, 146, 1440-1453, doi:10.1104/pp.107.111898.

85. Dixon, R.A. Natural products and plant disease resistance. Nature 2001, 411, 843-847, doi:10.1038/35081178.

86. Arras, G.; Agabbio, M.; Piga, A.; D’hallewin, G. FUNGICIDE EFFECT OF VOLATILE COMPOUNDS OF THYMUS CAPITATUS ESSENTIAL OIL. Acta Hortic 1995, 593-600, doi:10.17660/ActaHortic.1995.379.74.

87. Zhang, X.; Xia, C.; Li, C.; Nan, Z. Chemical composition and antifungal activity of the volatile oil from Epichloë gansuensis, endophyte-infected and non-infected Achnatherum inebrians. Science China. Life sciences 2015, 58, doi:10.1007/s11427-015-4837-0.

88. Holopainen, J.K.; Gershenzon, J. Multiple stress factors and the emission of plant VOCs. Trends in Plant Science 2010, 15, 176-184, doi:https://doi.org/10.1016/j.tplants.2010.01.006.

89. Guy, P.L.; Davis, L.T. Variation in the incidence of Barley yellow dwarf virus and in the ability of Neotyphodium endophytes to deter feeding by aphids (Rhopalosiphum padi) on Australasian tall fescue. Australasian Plant Pathology 2002, 31, 307-308, doi:10.1071/AP02032.

90. Kimmons, C.A.; Gwinn, K.D.; Bernard, E.C. Nematode reproduction on endophyte-infected and endophytefree tall fescue. Plant Disease 1990, 74, 757-761, doi:10.1094/PD-74-0757.

91. Pedersen, J.F.; Rodriguez-Kabana, R.; Shelby, R.A. Ryegrass Cultivars and Endophyte in Tall Fescue Affect Nematodes in Grass and Succeeding Soybean. 1988, 80, 811-814, doi:10.2134/agronj1988.00021962008000050024x.

92. Stewart, T.M.; Mercep, C.F.; Grante, J.L. Development of Meloidogyne naasi on endophyte-infected and endophyte-free perennial ryegrass. Australasian Plant Pathology 1993, 22, 40-41, doi:10.1071/APP9930040.

93. Elmi; West; Robbins; Kirkpatrick. Endophyte effects on reproduction of a root-knot nematode (Meloidogyne marylandi) and osmotic adjustment in tall fescue. 2000, 55, 166-172, doi:10.1046/j.1365-2494.2000.00210.x.

94. Guo, J.; McCulley, R.L.; Phillips, T.D.; McNear, D.H. Fungal endophyte and tall fescue cultivar interact to differentially affect bulk and rhizosphere soil processes governing $\mathrm{C}$ and $\mathrm{N}$ cycling. Soil Biology and Biochemistry 2016, 101, 165-174, doi:https://doi.org/10.1016/j.soilbio.2016.07.014.

95. Timper, P.; Gates, R.N.; Bouton, J.H. Response of Pratylenchus spp. in tall fescue infected with different strains of the fungal endophyte Neotyphodium coenophialum. Nematology 2005, 7, 105-110, doi:https://doi.org/10.1163/1568541054192216.

96. Panaccione, D.G. Origins and significance of ergot alkaloid diversity in fungi. FEMS Microbiology Letters 2005, 251, 9-17, doi:10.1016/j.femsle.2005.07.039.

97. Panaccione, D.; Kotcon, J.; Schardl, C.; Johnson, R.; Morton, J. Ergot alkaloids are not essential for endophytic fungus-associated population suppression of the lesion nematode, Pratylenchus scribneri, on perennial ryegrass. Nematology 2006, 8, 583-590, doi:https://doi.org/10.1163/156854106778614074.

98. Bacon, C.W.; Hinton, D.M.; Glenn, A.E. The Endophytic Niche and Grass Defense; Taylor \& Francis Group, LLC: 2009. 
99. Ball, O.; Christensen, M.; Prestidge, R. Effect of isolates of Acremonium endophyte on adult black beetle (Heteronychus arator) feeding; 1994; Volume 47.

100. Popay, A.; Tapper, B.; Podmore, C. Endophyteinfected meadow fescue and loline alkaloids affect Argentine stem weevil larvae. New Zealand Plant Protection 2009, 62, 19-27, doi:10.30843/nzpp.2009.62.4801.

101. Bastias, D.A.; Ueno, A.C.; Machado Assefh, C.R.; Alvarez, A.E.; Young, C.A.; Gundel, P.E. Metabolism or behavior: explaining the performance of aphids on alkaloid-producing fungal endophytes in annual ryegrass (Lolium multiflorum). Oecologia 2017, 185, 245-256, doi:10.1007/s00442-017-3940-2.

102. Bills, G.F.; González-Menéndez, V.; Martín, J.; Platas, G.; Fournier, J.; Peršoh, D.; Stadler, M. Hypoxylon pulicicidum sp. nov. (Ascomycota, Xylariales), a pantropical insecticide-producing endophyte. PloS one 2012, 7, e46687-e46687, doi:10.1371/journal.pone.0046687.

103. Craven, K.; Blankenship, J.; Leuchtmann, A.; Hignight, K.; Schardl, C. Hybrid fungal endophytes symbiotic with the grass Lolium pratense. Sydowia-Horn- 2001, 53, 44-73.

104. Fuchs, B.; Krauss, J. Can Epichloë endophytes enhance direct and indirect plant defence? Fungal Ecol 2019, 38, 98-103, doi:https://doi.org/10.1016/j.funeco.2018.07.002.

105. Sutherland, B.L.; Hoglund, J.H. Effect of ryegrasscontaining the endophyte Acremonium lolii, on the performance of associated white clover and subsequent crops. Proceedings of the New Zealand Grassland Association 1989, 50, 265-269.

106. Stevens, D.R.; Hickey, M.J. Effects of endophytic ryegrass on white clover. Proceedings of the International Symposium on Acremonium/Grass Interactions 1990.

107. Rice, E.L. Allelopathy, 2nd ed.; Academic Press: New York, 1984.

108. Vázquez-de-Aldana, B.R.; Romo, M.; García-Ciudad, A.; Petisco, C.; García-Criado, B. Infection with the fungal endophyte Epichloë festucae may alter the allelopathic potential of red fescue. Annals of Applied Biology 2011, 159, 281-290, doi:https://doi.org/10.1111/j.1744-7348.2011.00495.x.

109. Malinowski, D.P.; Belesky, D.P. Ecological importance of Neotyphodium spp. grass endophytes in agroecosystems. Grassland Science 2006, 52, 1-14, doi:https://doi.org/10.1111/j.1744-697X.2006.00041.x.

110. Guo, J.; McCulley, R.L.; McNear, D.H. Tall fescue cultivar and fungal endophyte combinations influence plant growth and root exudate composition. Front Plant Sci 2015, 6, doi:10.3389/fpls.2015.00183.

111. Sherif, E.; Hegazy, A.; Gomaa, N.; Hassan, N.H.; Hassan, M. Allelopathic effect of black mustard tissues and root exudates on some crops and weeds. Planta Daninha 2013, 31, 11-19, doi:10.1590/S0100-83582013000100002.

112. Yu, J.Q.; Matsui, Y. Phytotoxic substances in root exudates of cucumber (Cucumis sativus L.). Journal of Chemical Ecology 1994, 20, 21-31, doi:10.1007/BF02065988.

113. Lin, S.; Huangpu, J.J.; Chen, T.; Zhang, Z.Y.; Lin, W.X. Allelopathic potential and identification of allelochemicals in Pseudostellariae heterophylla rhizosphere soil in different crop rotations. Allelopathy Journal 2014, 33, 151-161.

114. Roberts, C.; Andrae, J. Tall Fescue Toxicosis and Management. Crop Management 2004, 3, 1-18, doi:https://doi.org/10.1094/CM-2004-0427-01-MG.

115. Strickland, J.R.; Oliver, J.W.; Cross, D.L. Fescue toxicosis and its impact on animal agriculture. Vet Hum Toxicol 1993, 35, 454-464.

116. Cross, D.L.; Redmond, L.M.; Strickland, J.R. Equine Fescue Toxicosis - Signs and and Solutions. Journal of Animal Science 1995, 73, 899-908.

117. Klotz, J.L.; Brown, K.R.; Bush, L.P.; Matthews, J.C.; Boling, J.A.; Strickland, J.R. Grazing high versus low endophyte-infected tall fescue reduces contractility of bovine lateral saphenous veins. Journal of Animal Science 2007, 85, 12-13. 
118. Trotta, R.J.; Harmon, D.L.; Klotz, J.L. Interaction of ergovaline with serotonin receptor 5-HT2A in bovine ruminal and mesenteric vasculature1. Journal of Animal Science 2018, 96, 4912-4922, doi:10.1093/jas/sky346.

119. Zhang, X.; Nan, Z.; Li, C.; Gao, K. Cytotoxic Effect of Ergot Alkaloids in Achnatherum inebrians Infected by the Neotyphodium gansuense Endophyte. J Agr Food Chem 2014, 62, 7419-7422, doi:10.1021/jf502264j.

120. Mote, R.S.; Hill, N.S.; Skarlupka, J.H.; Tran, V.T.; Walker, D.I.; Turner, Z.B.; Sanders, Z.P.; Jones, D.P.; Suen, G.; Filipov, N.M. Toxic tall fescue grazing increases susceptibility of the Angus steer fecal microbiota and plasma/urine metabolome to environmental effects. Scientific Reports 2020, 10, 2497, doi:10.1038/s41598-02059104-1.

121. Mote, R.S.; Hill, N.S.; Skarlupka, J.H.; Turner, Z.B.; Sanders, Z.P.; Jones, D.P.; Suen, G.; Filipov, N.M. Response of Beef Cattle Fecal Microbiota to Grazing on Toxic Tall Fescue. Appl Environ Microb 2019, 85, e00032-00019, doi:10.1128/aem.00032-19.

122. Mote, R.S.; Hill, N.S.; Uppal, K.; Tran, V.T.; Jones, D.P.; Filipov, N.M. Metabolomics of fescue toxicosis in grazing beef steers. Food Chem Toxicol 2017, 105, 285-299, doi:10.1016/j.fct.2017.04.020.

123. Rudgers, J.A.; Clay, K. Endophyte symbiosis with tall fescue: how strong are the impacts on communities and ecosystems?,. Fungal Biology Reviews 2007, 21, 107-124, doi:https://doi.org/10.1016/j.fbr.2007.05.002.

124. Conover, M.R.; Messmer, T.A. Feeding Preferences and Changes in Mass of Canada Geese Grazing Endophyte-Infected Tall Fescue. The Condor 1996, 98, 859-862, doi:10.2307/1369872.

125. Mote, R.S.; Filipov, N.M. Use of Integrative Interactomics for Improvement of Farm Animal Health and Welfare: An Example with Fescue Toxicosis. Toxins (Basel) 2020, 12, 633, doi:10.3390/toxins12100633.

126. Mueller, C.W.; Carminati, A.; Kaiser, C.; Subke, J.-A.; Gutjahr, C. Rhizosphere functioning and structural development as complex interplay between plants, microorganisms and soil minerals. Frontiers in Environmental Science 2019, 7, 130.

127. Mahmud, K.; Missaoui, A.; Lee, K.C.; Ghimire, B.; Presley, H.W.; Makaju, S. Rhizosphere Microbiome Manipulation for Sustainable Crop Production. Current Plant Biology 2021, 100210.

128. Jones, D.L.; Nguyen, C.; Finlay, R.D. Carbon flow in the rhizosphere: carbon trading at the soil-root interface. Plant and soil 2009, 321, 5-33.

129. Chauhan, A.; Saini, R.; Sharma, J.C. Plant growth promoting rhizobacteria and their biological properties for soil enrichment and growth promotion. Journal of Plant Nutrition 2021, 1-27.

130. Johansson, J.F.; Paul, L.R.; Finlay, R.D. Microbial interactions in the mycorrhizosphere and their significance for sustainable agriculture. FEMS microbiology ecology 2004, 48, 1-13.

131. Schlaeppi, K.; Bulgarelli, D. The plant microbiome at work. Molecular Plant-microbe interactions 2015, 28, 212217.

132. Alori, E.; Glick, B.; Babalola, O. Microbial phosphorus solubilization and its potential for use in sustainable agriculture. Front Microbiol. 2017b; 8: 971. 2017.

133. Chung, Y.A.; Rudgers, J.A. Plant-soil feedbacks promote negative frequency dependence in the coexistence of two aridland grasses. Proceedings of the Royal Society B: Biological Sciences 2016, 283, 20160608.

134. Tilman, D. Resource Competition and Community Structure.(MPB-17), Volume 17; Princeton university press: 2020.

135. MacArthur, R.H. Population ecology of some warblers of northeastern coniferous forests. Ecology 1958, 39, 599-619.

136. Grime, J.P. Evidence for the existence of three primary strategies in plants and its relevance to ecological and evolutionary theory. The american naturalist 1977, 111, 1169-1194. 
137. Bergmann, G.T.; Bates, S.T.; Eilers, K.G.; Lauber, C.L.; Caporaso, J.G.; Walters, W.A.; Knight, R.; Fierer, N. The under-recognized dominance of Verrucomicrobia in soil bacterial communities. Soil Biology and Biochemistry 2011, 43, 1450-1455.

138. Vandenkoornhuyse, P.; Quaiser, A.; Duhamel, M.; Le Van, A.; Dufresne, A. The importance of the microbiome of the plant holobiont. New Phytologist 2015, 206, 1196-1206.

139. Calvo, P.; Nelson, L.; Kloepper, J.W. Agricultural uses of plant biostimulants. Plant and soil 2014, $383,3-41$.

140. Vorholt, J.A.; Vogel, C.; Carlström, C.I.; Müller, D.B. Establishing causality: opportunities of synthetic communities for plant microbiome research. Cell Host $\mathcal{E}$ Microbe 2017, 22, 142-155.

141. Castellano-Hinojosa, A.; Strauss, S.L. Insights into the taxonomic and functional characterization of agricultural crop core rhizobiomes and their potential microbial drivers. Sci Rep 2021, 11, 1-11.

142. Hayat, R.; Ali, S.; Amara, U.; Khalid, R.; Ahmed, I. Soil beneficial bacteria and their role in plant growth promotion: a review. Annals of Microbiology 2010, 60, 579-598, doi:10.1007/s13213-010-0117-1.

143. Tisdall, J.M. Possible role of soil microorganisms in aggregation in soils. Plant Soil 1994, 159, 115-121, doi:10.1007/BF00000100.

144. Mendes, R.; Garbeva, P.; Raaijmakers, J.M. The rhizosphere microbiome: significance of plant beneficial, plant pathogenic, and human pathogenic microorganisms. FEMS Microbiology Reviews 2013, 37, 634-663, doi:10.1111/1574-6976.12028.

145. Abd-Elsalam, K.; Almohimeed, I.; Moslem, M.; Bahkali, A. M13-microsatellite PCR and rDNA sequence markers for identification of Trichoderma (Hypocreaceae) species in Saudi Arabian soil. Genetics 2010, 9, 20162024.

146. Marks, S.; Clay, K. Physiological responses of Festuca arundinacea to fungal endophyte infection. New Phytol 1996, 133, 727-733, doi:DOI 10.1111/j.1469-8137.1996.tb01941.x.

147. Franzluebbers, A.J.; Hill, N.S. Soil Carbon, Nitrogen, and Ergot Alkaloids with Short- and Long-Term Exposure to Endophyte-Infected and Endophyte-Free Tall Fescue. Soil Science Society of America Journal 2005, 69, 404-412, doi:10.2136/sssaj2005.0404.

148. Omacini, M.; Chaneton, E.J.; Ghersa, C.M.; Otero, P. Do foliar endophytes affect grass litter decomposition? A microcosm approach using Lolium multiflorum. Oikos 2004, 104, 581-590, doi:DOI 10.1111/j.00301299.2004.12915.x.

149. Van Hecke, M.M.; Treonis, A.M.; Kaufman, J.R. How does the Fungal Endophyte Neotyphodium coenophialum Affect Tall Fescue (Festuca arundinacea) Rhizodeposition and Soil Microorganisms? Plant Soil 2005, 275, 101-109, doi:10.1007/s11104-005-0380-2.

150. Malinowski, D.P.; Belesky, D.P. Neotyphodium coenophialum-endophyte infection affects the ability of tall fescue to use sparingly available phosphorus. Journal of Plant Nutrition 1999, 22, 835-853, doi:10.1080/01904169909365675.

151. Malinowski, D.P.; Zuo, H.; Belesky, D.P.; Alloush, G.A. Evidence for copper binding by extracellular root exudates of tall fescue but not perennial ryegrass infected with Neotyphodium spp. endophytes. Plant Soil 2004, 267, 1-12, doi:DOI 10.1007/s11104-005-2575-y.

152. Franzluebbers, A.J. Potential C and N mineralization and microbial biomass from intact and increasingly disturbed soils of varying texture. Soil Biology and Biochemistry 1999, 31, 1083-1090, doi:https://doi.org/10.1016/S0038-0717(99)00022-X.

153. Hosseini, F.; Mosaddeghi, M.R.; Hajabbasi, M.A.; Sabzalian, M.R. Influence of tall fescue endophyte infection on structural stability as quantified by high energy moisture characteristic in a range of soils. Geoderma 2015, 249-250, 87-99, doi:https://doi.org/10.1016/j.geoderma.2015.03.013. 
154. Handayani, I.P.; Coyne, M.S.; Phillips, T.D. Soil organic carbon fractions differ in two contrasting tall fescue systems. Plant Soil 2011, 338, 43-50, doi:10.1007/s11104-010-0352-z.

155. Buta, J.G.; Spaulding, D.W. Allelochemicals in tall fescue-abscisic and phenolic acids. J Chem Ecol 1989, 15, 1629-1636, doi:10.1007/BF01012389.

156. Xue, S.; Yang, X.; Liu, G.; Gai, L.; Zhang, C.; Ritsema, C.J.; Geissen, V. Effects of elevated CO2 and drought on the microbial biomass and enzymatic activities in the rhizospheres of two grass species in Chinese loess soil. Geoderma 2017, 286, 25-34, doi:https://doi.org/10.1016/j.geoderma.2016.10.025.

157. Naylor, D.; DeGraaf, S.; Purdom, E.; Coleman-Derr, D. Drought and host selection influence bacterial community dynamics in the grass root microbiome. The ISME Journal 2017, 11, 2691-2704, doi:10.1038/ismej.2017.118.

158. East, R. Microbiome: soil science comes to life. Nature 2013, 501, S18-S19.

159. Groben, G.; Luo, J.; Walsh, E.; Qu, H.; Meyer, W.; Bonos, S.; Clarke, B.; Zhang, N. The Microbiome Associated with Tall Fescue Under Drought Stress. In Proceedings of the Twenty-Seventh Annual Rutgers Turfgrass Symposium, New Brunswick, NJ, 2018; p. 15.

160. Masmoudi, K.; Aziz, M.A.; Shamim, A.; Sabeem, M.; Hazzouri, K.M.; Amiri, K.M. Metagenomics of Beneficial Microbes in Abiotic Stress Tolerance of Date Palm. In The Date Palm Genome, Vol. 2; Springer: 2021; pp. 203214.

161. Glick, B.R.; Gamalero, E. Recent Developments in the Study of Plant Microbiomes. Microorganisms 2021, 9, doi:10.3390/microorganisms9071533.

162. Wei, F.; Feng, H.; Zhang, D.; Feng, Z.; Zhao, L.; Zhang, Y.; Deakin, G.; Peng, J.; Zhu, H.; Xu, X. Composition of Rhizosphere Microbial Communities Associated With Healthy and Verticillium Wilt Diseased Cotton Plants. Front Microbiol 2021, 12, 618169-618169, doi:10.3389/fmicb.2021.618169.

163. Kim, B.; Song, G.C.; Ryu, C.M. Root Exudation by Aphid Leaf Infestation Recruits Root-Associated Paenibacillus spp. to Lead Plant Insect Susceptibility. J Microbiol Biotechnol 2016, 26, 549-557, doi:10.4014/jmb.1511.11058.

164. Antoniou, A.; Tsolakidou, M.-D.; Stringlis, I.A.; Pantelides, I.S. Rhizosphere Microbiome Recruited from a Suppressive Compost Improves Plant Fitness and Increases Protection against Vascular Wilt Pathogens of Tomato. Front Plant Sci 2017, 8, doi:10.3389/fpls.2017.02022.

165. Mahmud, K.; Franklin, D.; Ney, L.; Cabrera, M.; Habteselassie, M.; Hancock, D.; Newcomer, Q.; Subedi, A.; Dahal, S. Improving inorganic nitrogen in soil and nutrient density of edamame bean in three consecutive summers by utilizing a locally sourced bio-inocula. Organic Agriculture 2021, 1-11.

166. Ney, L.; Franklin, D.; Mahmud, K.; Cabrera, M.; Hancock, D.; Habteselassie, M.; Newcomer, Q. Examining trophic-level nematode community structure and nitrogen mineralization to assess local effective microorganisms' role in nitrogen availability of swine effluent to forage crops. Applied soil ecology 2018, 130, 209-218.

167. Zhu, J.; Li, M.; Whelan, M. Phosphorus activators contribute to legacy phosphorus availability in agricultural soils: A review. Science of the Total Environment 2018, 612, 522-537.

168. Wyngaard, N.; Cabrera, M.L.; Jarosch, K.A.; Bünemann, E.K. Phosphorus in the coarse soil fraction is related to soil organic phosphorus mineralization measured by isotopic dilution. Soil Biology and Biochemistry 2016, 96, 107-118.

169. Hinsinger, P. Bioavailability of soil inorganic P in the rhizosphere as affected by root-induced chemical changes: a review. Plant and soil 2001, 237, 173-195. 
170. Akhtar, M.S.; Oki, Y.; Adachi, T. Mobilization and Acquisition of Sparingly Soluble P-Sources by Brassica Cultivars under P-Starved Environment II. Rhizospheric pH changes, Redesigned Root Architecture and PiUptake Kinetics. Journal of integrative plant biology 2009, 51, 1024-1039.

171. Peng, X.; Wang, W. Stoichiometry of soil extracellular enzyme activity along a climatic transect in temperate grasslands of northern China. Soil Biology and Biochemistry 2016, 98, 74-84.

172. Ding, N.; Guo, H.; Kupper, J.V.; McNear Jr, D.H. Phosphorus source and Epichloë coenophiala strain interact over time to modify tall fescue rhizosphere microbial community structure and function. Soil Biology and Biochemistry 2021, 154, 108125.

173. Roberts, E.; Lindow, S. Loline alkaloid production by fungal endophytes of Fescue species select for particular epiphytic bacterial microflora. The ISME Journal 2014, 8, 359-368, doi:10.1038/ismej.2013.170.

174. Roberts, E.L.; Ferraro, A. Rhizosphere microbiome selection by Epichloë endophytes of Festuca arundinacea. Plant Soil 2015, 396, 229-239, doi:10.1007/s11104-015-2585-3.

175. Fließach, A.; Mader, P. Carbon source utilization by microbial communities in soils under organic and conven- tional farming practice. In: Insam H, Rangger A (eds) Microbial communities - functional versus structural approaches. . Springer-Verlag, Berlin 1997, 236-241.

176. Jenkins, M.B.; Franzluebbers, A.J.; Humayoun, S.B. Assessing short-term responses of prokaryotic communities in bulk and rhizosphere soils to tall fescue endophyte infection. Plant Soil 2006, 289, 309-320, doi:10.1007/s11104-006-9141-0.

177. Buyer, J.S.; Zuberer, D.A.; Nichols, K.A.; Franzluebbers, A.J. Soil microbial community function, structure, and glomalin in response to tall fescue endophyte infection. Plant Soil 2011, 339, 401-412, doi:10.1007/s11104010-0592-y.

178. Radhakrishnan, R.; Hashem, A.; Abd Allah, E.F. Bacillus: A Biological Tool for Crop Improvement through Bio-Molecular Changes in Adverse Environments. Front Physiol 2017, 8, 667-667, doi:10.3389/fphys.2017.00667.

179. Mahmud, K.; Lee, K.; Hill, N.S.; Missaoui, A. Influence of Tall Fescue Epichloe endophytes on Rhizosphere Soil Microbiome. Research Square 2021, doi:10.21203/rs.3.rs-614409/v1.

180. Ju, Y.; Zhong, R.; Christensen, M.J.; Zhang, X. Effects of Epichloë gansuensis Endophyte on the Root and Rhizosphere Soil Bacteria of Achnatherum inebrians Under Different Moisture Conditions. Front Microbiol 2020, 11, doi:10.3389/fmicb.2020.00747.

181. Liang, Y.; Wang, H.; Li, C.; Nan, Z.; Li, F. Effects of feeding drunken horse grass infected with Epichloë gansuensis endophyte on animal performance, clinical symptoms and physiological parameters in sheep. BMC Veterinary Research 2017, 13, doi:10.1186/s12917-017-1120-6.

182. Mormile, B.W. Influence of Seed Microbiome on Fitness of $<\mathrm{i}>$ Epichloë $</ \mathrm{i}>$ Infected Tall Fescue Seedlings. M.S., Southern Connecticut State University, Ann Arbor, 2016.

183. Rostás, M.; Cripps, M.G.; Silcock, P. Aboveground endophyte affects root volatile emission and host plant selection of a belowground insect. Oecologia 2015, 177, 487-497, doi:10.1007/s00442-014-3104-6.

184. Smith, S.E.; Gianinazzi-Pearson, V. Physiological Interactions Between Symbionts in Vesicular-Arbuscular Mycorrhizal Plants. Annual Review of Plant Physiology and Plant Molecular Biology 1988, 39, 221-244, doi:10.1146/annurev.pp.39.060188.001253.

185. Omacini, M.; Eggers, T.; Bonkowski, M.; Gange, A.C.; Jones, T.H. Leaf endophytes affect mycorrhizal status and growth of co-infected and neighbouring plants. 2006, 20, 226-232, doi:10.1111/j.1365-2435.2006.01099.x.

186. Müller, J. Artificial infection by endophytes affects growth and mycorrhizal colonisation of Lolium perenne. Functional Plant Biology 2003, 30, 419-424, doi:https://doi.org/10.1071/FP02189. 
187. Vignale, M.V.; Iannone, L.J.; Scervino, J.M.; Novas, M.V. Epichloë exudates promote in vitro and in vivo arbuscular mycorrhizal fungi development and plant growth. Plant Soil 2018, 422, 267-281, doi:10.1007/s11104017-3173-5.

188. Zhong, R.; Xia, C.; Ju, Y.; Zhang, X.; Duan, T.; Nan, Z.; Li, C. A foliar Epichloë endophyte and soil moisture modified belowground arbuscular mycorrhizal fungal biodiversity associated with Achnatherum inebrians. Plant Soil 2021, 458, 105-122, doi:10.1007/s11104-019-04365-7.

189. Li, F.; Deng, J.; Nzabanita, C.; Li, Y.; Duan, T. Growth and physiological responses of perennial ryegrass to an AMF and an Epichloë endophyte under different soil water contents. Symbiosis 2019, 79, 151-161, doi:10.1007/s13199-019-00633-3.

190. Guo, Y.; Gao, P.; Li, F.; Duan, T. Effects of AM fungi and grass endophytes on perennial ryegrass Bipolaris sorokiniana leaf spot disease under limited soil nutrients. European Journal of Plant Pathology 2019, 154, 659671, doi:10.1007/s10658-019-01689-z.

191. Charitha Devi, M.; Reddy, M.N. Phenolic acid metabolism of groundnut (Arachis hypogaea L.) plants inoculated with VAM fungus and Rhizobium. Plant Growth Regulation 2002, 37, 151-156, doi:10.1023/A:1020569525965. 